\begin{tabular}{c}
\hline Review of \\
ECONOMICS \\
and \\
INSTITUTIONS
\end{tabular}

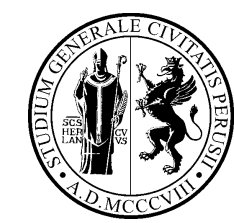

www.rei.unipg.it

\title{
Institutions and Economic Performance: What Can Be Explained?
}

\author{
Simon Commander \\ IE Business School, Madrid \\ EBRD and Altura Advisers
}

\author{
Zlatko Nikoloski ${ }^{凶}$ \\ University College London
}

\begin{abstract}
Institutions are now widely believed to be important in explaining performance. In this paper, we analyze whether commonly used measures of institutions have any significant, measurable impact on performance, whether of countries or firms. We look at three 'levels' of institutions and associated conjectures. The first concerns whether the political system affects performance. The second concerns whether the business and investment environment affects the performance of countries and the third concerns whether perceived business constraints directly affect the performance of firms. In all instances, we find little evidence of a robust link between widely used measures of institutions and our indicators of performance. We consider why this might be the case and argue that mis-measurement, mis-specification, complexity and non-linearity are all relevant factors.
\end{abstract}

JEL classification: D24, L21, 012, P48

Keywords: institutions, economic growth, development, firm performance

An earlier version of this paper was presented at the conference on 'Enforcement, Evasion and Informality: Theory and Practice: In Honour of Katherine Terrell" that was held at the University of Michigan on 4-6 June, 2010.

\footnotetext{
${ }^{\square}$ Address: University College London - Gower Street, London WC1E 6BT, UK (Email: z.nikoloski@ucl.ac.uk).
}

\section{Recommended Citation}

Commander, S., \& Nikoloski, Z. (2011). Institutions and Economic Performance: What Can be Explained? Review of Economics and Institutions, 2(2), Article 3. doi: 10.5202/rei.v2i2.33. Retrieved from: http://www.rei.unipg.it/rei/article/view/33 


\section{Introduction}

Twenty five years ago most analysis of the economic performance of countries or firms would have hardly mentioned the role of institutions. Nowadays, the reverse seems true. Barely a paper goes by without invoking the influence of institutions on performance. Part of this flourishing can be attributed to the impetus given by a wider analytical literature, but part can also be attributed to one of its consequences: the proliferation of datasets aiming to measure a wide gamut of institutional forms, ranging from political systems to labour legislation and taxation systems. Such datasets normally put together observations across countries and/or regions and other more disaggregated units of analysis. In this proliferation, a simple - but accurate - characterization of the literature would be the apparent association of institutions and measures of their quality with economic performance. Stated bluntly, there seems now to be a broad consensus that, for example, political systems influence performance with democratic systems, in particular, being better for growth than non-democratic ones, that democracies tend to have 'better' business environments - normally defined as those with lower regulation and fewer impediments to investment and transacting - and that 'better' business environments tend to be associated with stronger economic growth when measured at firm level. There are, in addition, extensions that also relate subjective measures of well-being - such as happiness or satisfaction - to both political systems and other institutional features. Finally, this wide consensus has also been echoed in the political and economic dialogue linking international financial institutions, as well as bilateral agencies, with developing countries. One manifestation of this has been the World Bank's Doing Business, where disaggregated measures of the business environment have been compiled across a large range of countries with an explicit view to influencing the content and direction of policy, often through the encouragement of rivalry or horse races between countries in the implementation of reforms.

In the light of this apparent convergence in analysis and policy, our paper takes a close look at how robust is the relationship between institutions whether of political regimes or of components of the business environment - and economic performance. As such, it operates at several 'levels' and with several different types of data. The paper is organized as follows. Section 2 examines the relationship between political systems - principally the presence or absence of democracy - and performance, as measured principally by growth in per capita income and real GDP growth. Section 3 then shifts to looking at whether measures of the business environment affect growth at country level using for the most part the influential Doing Business dataset, while Section 4 looks at the same question using firm level data, in this instance mainly the Business Environment and Enterprise Performance Survey (BEEPS). In all instances, we find little evidence for a 
robust relationship between these various institutional measures and performance. Section 5 then asks why this might be the case and focuses on a combination of factors, including analytical reasons as well as those relating to measurement.

\section{Political Systems and Performance}

The hypothesized relationship between political institutions and growth has been traced to a number of characteristics. Most generally, it has been argued that features of democracy such as political pluralism, institutional checks and balances, and the periodic renewal of policymakers through elections protect the economic system against abusive or predatory behaviour typical of most authoritative regimes (see Comeau, 2003). The democratic process is widely viewed as more suitable to economic prosperity because of its ability to nurture civil liberties and secure property and contract rights. Consequently, it provides agents with incentives to undertake investment and maximize welfare. Through defined and protected property rights, democracy makes it possible for individuals to examine opportunity costs freely and to engage in entrepreneurial behaviour, as argued, inter alia, by North (1990). A key conditioning variable, determining much of the effect of regime type on growth, is the expectation of citizens and investors that they will be able to capture gains from exchange and protect returns to investment. In contrast, autocrats generally cannot make credible commitments to securing such rights (see Olson, 1982). A variant of this argument concerns the longevity of regimes. Olson (1993) has argued that the way in which a regime will function will depend on its horizon. Most autocratic regimes tend to behave as if they have short horizons giving rise to looting and other behaviour antithetical to growth. Przeworski and Limongi (1993) have argued that the court system, independent judiciary, and respect for law and individual rights that are needed for a lasting democracy are also required for security of property and contract rights. However, it is not clear how these rights are necessarily more secure under democracy. Further, when looking at democracies' economic performance, Olson (1982) argues that democracies succumb to 'institutional sclerosis' over time as special interests organize to capture rents. Indeed, some forms of dictatorship may actually be more encompassing if democratic institutions allow a majority to entrench its position and special interests to gain protection. This leads to some ambiguity in the prediction of how political regime will influence performance. An additional criticism of democracies has been their proclivity to engage in redistributive politics that can have a negative impact on growth $]_{1}^{1}$ autocracies in contrast may be under no such pressure. Olson and

1 For example, see Barro (1996, 1997). Fernandez and Rodrik (1991) show that rational voters may choose not to support efficiency-enhancing reforms because of individual uncertainty about payoffs. Further, governments facing elections may pursue policies that 
others have argued that stable autocratic regimes can deliver growth successfully. Yet, autocratic regimes tend not to be stable over particularly long periods of time, not least due to the ways in which the products of growth tend to be distributed. ${ }^{2}$ Rodrik (2000) has argued that the conflict management possibilities in countries with participatory institutions yield less growth volatility than in non-democratic societies ${ }^{3}$ In addition, he claims that democracies fare better at adjusting policies in response to shocks..$^{4}$

\subsection{Political Systems and Performance: Estimations}

There is a body of literature that has examined the central question of whether political systems and institutions affect growth differentially. Weede (1983) used a sample of 89 countries over the period from 1960 until 1979 and found a negative relationship for the full sample, no relationship for the less developed countries and a negative relationship for countries for which the ratio of the government revenue and the gross domestic product is higher than 20 percent. Estimation was by OLS and no attempt was made to deal with endogeneity of the measures. Kormandi and Meguire (1985) also estimated with OLS using a Gastil dummy for 47 countries for the period from 1950 to 1977.5 They - as well as Marsh (1988) using a larger sample - found no relationship between the two variables. Grier and Tullock (1989) also used OLS with the Gastil measure of democracy with a sample of 89 developing countries and ran separate regressions for Africa, Asia and the Americas. They used a pooled cross section time series (5 year averages) and found a negative relationship for Africa and no relationship for the Americas or Asia. Barro (1996) was the first to try addressing the endogeneity issue through use of instruments, mainly lagged values. Relating

maximize the prospects of re-election, even if these are detrimental to long-term economic growth. Przeworski and Limongi (1993) argue that democracies may favour policies that give priority to current consumption.

2 A different variant of this theme can be found in the literature on development and innovation where autocratic, coordinated regimes - as in South Koreas in the 1960s-1980s - can deliver extensive growth but have properties that make the shift to greater innovation led growth difficult, if not impossible, see Aghion et al. (2007) who extend the Gerschenkron framework.

3 We also generated a simple scatter relating the democracy scores in both Freedom House and Polity IV databases that we use in this paper to the average standard deviation of per capita growth. They strongly suggest that non-democracies tend to have significantly higher variation in growth over the periods from 1972-2009 (FH) and 1960-2009 (Polity).

4 See also Rodrik $(1997,1999)$. Sah $(1991)$ broadens this argument to claim that autocracies' performance should be more variable than the performance of the democracies, due to human fallibility. In societies where only a small group of people are responsible for the most relevant decisions, risk in decision-making is not well diversified.

5 One of the most well known indices of democracy is the Gastil index. It provides a good coverage of countries and years (from 1972 onwards). In its nature it is quite similar to the Freedom House index as it provides an account of the political rights and civil liberties present in a given country. 
growth rates of real per capita GDP over three periods to the Gastil measure of political rights, he found a negative but insignificant relationship between democracy and growth. However, he also found evidence for an inverted $U$ curve relationship between democracy and growth. To test for non-linearities, dummy variables for democracy were used, corresponding to low, medium and high, as indicated by the Gastil measure. The findings appeared to reject linearity with a middle level of democracy being most tightly associated with performance. A similar conclusion held when entering the democracy indicator in quadratic form, with higher levels of political freedom being associated with worse performance. This was attributed to the impact of redistribution. Although using instruments, the paper did not take into account unobserved heterogeneity or fixed effects. Barro and Lee (1993) also used data for the period from 1973 to 1985 for a large sample of countries and found no relationship between democracy and growth. Other papers, such as Levine and Renelt (1992) and De Haan and Siermann (1995) have also used the Gastil index but found no robust relationship between the measure and performance.

We now revisit the relationship between political system - principally democracy - and growth using 5 year averages for a large sample of 159 developed, developing and transition economies over the period from 1960 to 2009. We opt for a gradient measure of democracy as we are trying to estimate the impact of regimes on growth in the longer period (rather than analyzing the impact of transitional democratizations). As such, we use several measures of democracy. The first is the Freedom House index measure of civil liberties and political rights. This index assigns the countries a specific score corresponding to their level oh political rights and civil liberties in the country ( 1 being most democratic and 7 being the least democratic). We also derive a variable democracy which is a simple average of political rights and civil liberties. A second measure is also applied using the democracy data taken from Polity IV. That dataset also offers a gradient approach to measuring the level of democracy, ranking countries on a spectrum ranging from fully institutionalized autocracies through mixed or incoherent autocratic regimes to fully institutionalized democracies. The nature of each regime is measured on a 20 point scale ranging from -10 (full autocracy) to +10 (full democracy) ${ }^{6}$ It should be noted however that the definition of democracy in Polity IV is narrower than the Freedom House Index.7 We also use the Cheibub et al. (2009) dataset in which a dummy variable is used when a country is deemed democratic ${ }^{8}$ As a robustness check we also experiment

6 We also transform the Polity IV variable by subtracting the autocracy score from the democracy score (also adding 10) thus arriving at a gradient measure of democracy that ranges from 0 to 20 ( 0 being perfectly autocratic and 20 being perfectly democratic).

7 Unlike the Freedom House Index that focuses on both political right and civil liberties, Polity IV consists of six component measures that record key qualities of executive recruitment, constraints on the executive authority and political competition.

8 To be democratic the following conditions need to be satisfied: (a) direct election of 
with a measure of the duration of regimes (also taken from Polity IV dataset) conditional on whether a country has been a democracy or an autocracy..$^{9}$

We implement the following:

$$
y / l_{i, t}=\alpha+\beta D E M O C R A C Y_{i, t}+\gamma X_{i, t}+\epsilon_{i, t}
$$

where, $X$ is a vector of control variables (the level of economic development, openness, inflation, gross secondary education enrollment rate, life expectancy, population and government expenditure.$^{10}$ We adopt state-ofthe-art Generalized Method of Moments (GMM) estimation to deal with the critical issues of endogeneity and unobserved heterogeneity (see Roodman, 2006). Tables 1 and 2 report our estimations when growth in per capita income and real GDP growth are our dependent variables. It can be seen that in no instance do any of the reported right hand sides have significance. The data is annual covering the period 1960-2009. However, given the problems associated with proliferation of the number of instruments (Roodman, 2006), we opted for averaging the data ending up with ten 5-year periods. In order to deal with the endogeneity of some of the regressors we used lags of the endogenous variables (lags 1-4). Of the regressors used in the model, GDP per capita and GDP per capita squared, trade openness, inflation, life expectancy, school enrollment and government expenditure were considered as endogenous, while population was considered as pre-determined. Model 1 uses a Freedom House average of the civil liberties and political rights. The scale of the index is inverted, increasing in the degree of autocracy. The coefficient of the estimation is positive suggesting a negative link between democracy and growth (i.e., countries with worse civil liberties and political rights tend to grow more). However, the coefficient is insignificant. Model 2 estimates in non-linear form and suggests that at lower levels of democracy an increase in political rights and civil liberties may increase growth (similar to Barro). In Model 3 Polity IV is used in linear form and the estimate suggests that an increase in democracy will be associated with growth. In non-linear forms, the results are ambiguous.

the executive either by popular vote or election of committed delegates; (b) legislature is elected by either direct or indirect election, (c) multiple parties are legally present, (d) de facto, there are multiple parties in the political system, (e), multiple parties are represented in the legislature and (f) incumbents do not usurp power while in office.

9 It is also worth noting that we experimented with ICRG (International Country Risk Guide) as a possible measure of democracy. However, ICRG measures are focused mostly on measuring policy outcomes rather than institutions and some of the credit risk scores could be biased.

10 Data for per capita GDP growth comes from the World Penn Tables. Data for real GDP growth are taken from the World Development Indicators (WDI). Most controls are also drawn from the WDI, although the inflation measure is from the IMF's International Financial Statistics. 


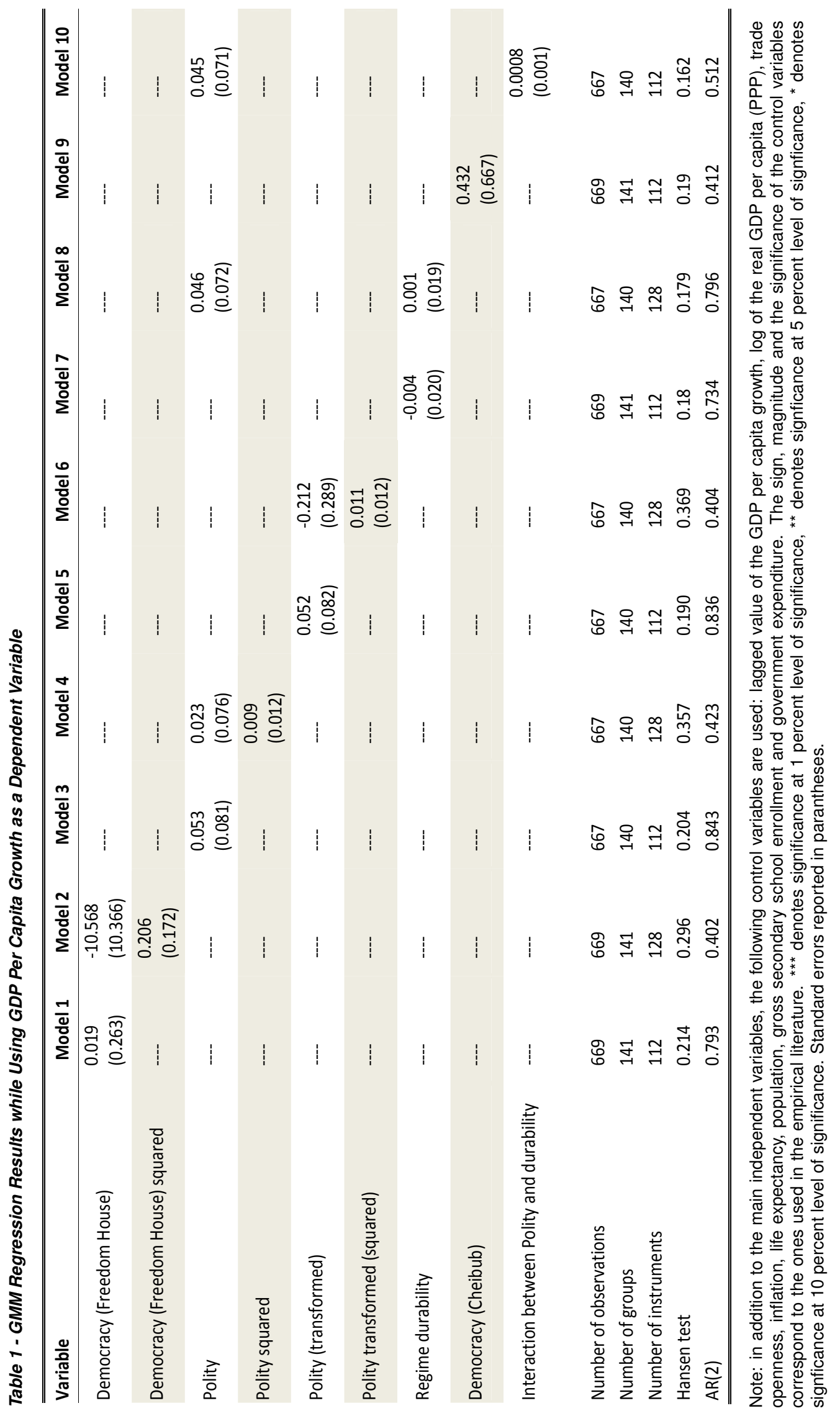

http://www.rei.unipg.it/rei/article/view/33 


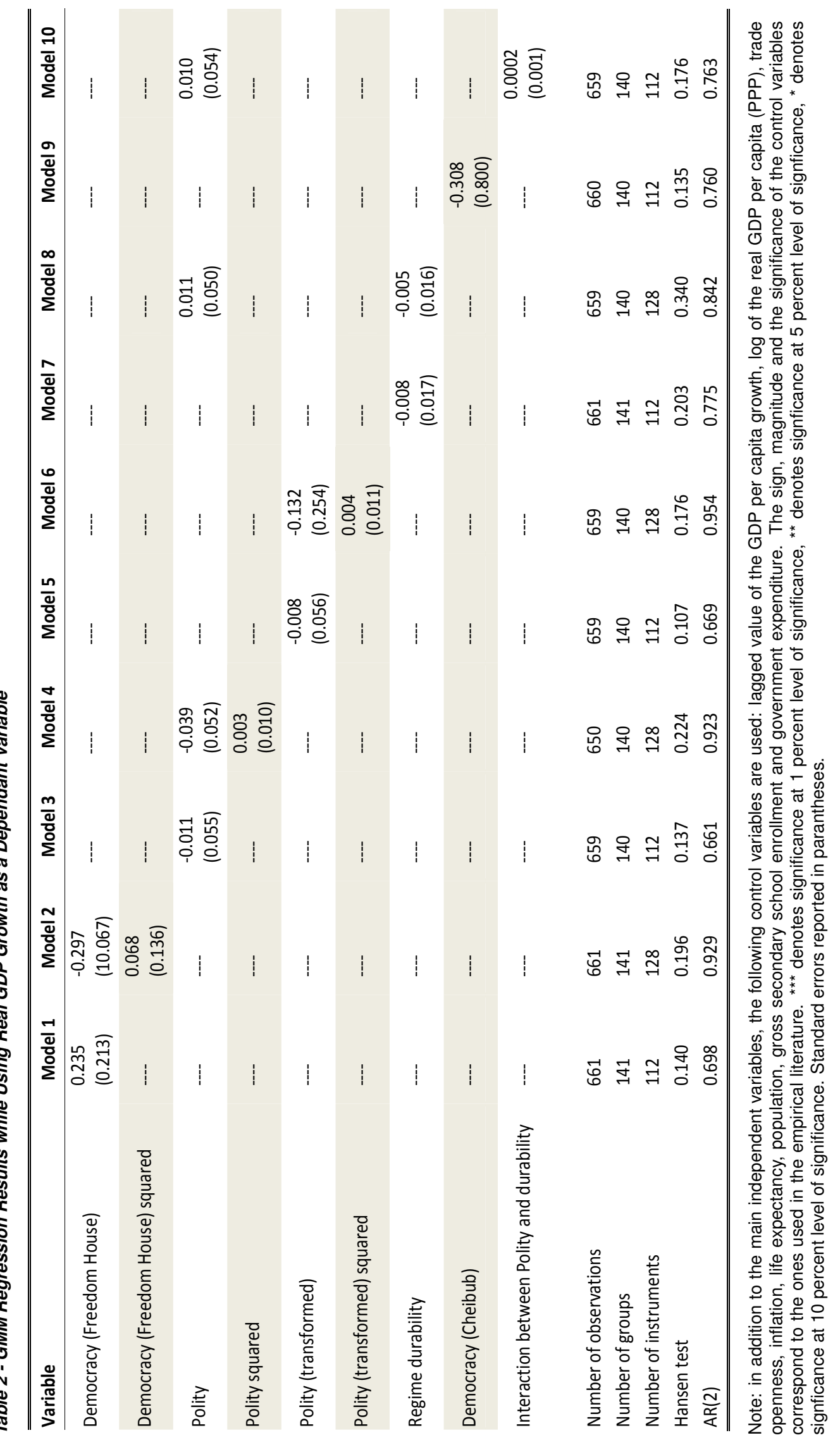


Models 5 and 6 use a slightly transformed index - adding 10 points in order to arrive at a continuous variable ranging from 0 to 20 - and these suggest that in the linear specification per capita growth increases with democracy. In the non-linear form, it suggests that there is a threshold beyond which this positive association holds. We also explore the relationship using a measure of durability, conditional upon the nature of the regime, in Models 7 and 8. The sign switches across estimates and both are insignificant. Model 9 uses the Cheibub et al. (2009) measure - the coefficient is positive, implying that more democracy is associated with per capita growth but it is insignificant. Finally, Model 10 includes the Polity variable as well as an interaction between that measure and durability. Both coefficients are positive but insignificant. Table 2 repeats using real GDP growth as the dependent variable. The same results broadly hold.

In order to assess the sensitivity of our results to different estimation techniques, we also estimate the same equations using OLS and panel fixed effects. Tables A1 and A2 in the Appendix contain estimates obtained with OLS, while Tables B1 and B2 in the Appendix have those for panel fixed effects. No robust relationship between democracy and institutions whether estimating with per capita growth or GDP growth as the dependent variable can be established.

In sum, our efforts to identify an association between political regime - notably democracy - and growth can find no such association. Further, given that earlier estimates that did find such a link used biased estimation techniques, we consider that our results represent a more reliable indicator. We return to the possible reasons for why these estimates are so inconclusive in Section 5 below.

\section{Institutions and Performance at Country Level}

Centre-stage in the policy dialogue of recent times has been the proposition that the institutional texture of a country crucially affects how business and investment are done. Business environments that have lower regulation, higher predictability and greater transparency have generally been regarded as being supportive for growth. There is now a very copious literature trying to establish this argument across a great number of countries and periods of time (see, for example, Dollar et al., 2005; Loayza et al., 2004; De Soto, 2000). In addition, these basic propositions have entered the policy canon and characteristically form a part of the dialogue between developing countries and external lenders. While there are now a number of data sources that attempt to document country level business environments, the most notable remains the World Bank's 'Doing Business' survey. Doing Business employs a template questionnaire targeted at local professionals in a variety of fields, including lawyers, officials and consultants. The questionnaire is organised around a hypothetical business case and then admin- 
istered to a range of expert respondents in each country.

It has now been administered up to seven times between 2003 and 2009 with over 5000 experts being contacted in 175 countries. In recent years, information on ten indicators has been collected 11 However, information on only five sets of indicators has been collected for all years since 2003 (starting a business, employment regulation; enforcing contracts; getting credit and closing a business). The full set of Doing Business indicators are also put together in an aggregate ranking that aims to summarise a country's ease of doing business. It should be noted that each country has a unique indicator, a heroic assumption for large and diverse countries, such as Brazil or India. A number of quite restrictive assumptions are also made about the representative firm (see Commander and Tinn, 2009 for more details). The philosophy behind Doing Business has causality running from institutions to performance. Identifying these effects raises obvious issues of endogeneity. Performance can obviously be summarised by country level growth but data limitations mean that, at best, only the relationship between growth over the period 2003-2007 and the Doing Business indicators available for 2003 could be explored. But looking at the growth rate over a very short period of time that could have been affected by business cycles is problematic. The impact of institutions on growth is far more likely to be a longer term phenomenon and might not affect performance immediately. Further, it would not be possible to address the issues arising from potential reverse causality due to the absence of suitable instruments. The countries that have a potential to grow faster may have had more incentives to develop institutions. This limits the robustness of any estimation using aggregate data. However, there are also hypothesised relationships between the Doing Business indicators and, what can be termed, intermediate outcomes. These are indicated in Table 3. What we now do is to relate recent available data on the intermediate indicators to the contemporaneous Doing Business indicators. The estimates also use as controls the log of PPP adjusted GDP, government expenditure to GDP and secondary school enrolment. These results are reported in Table 4 . The results in the first column include only one relevant group of Doing Business indicators. The second column reports results when Doing Business indicators from all relevant categories are jointly included. Exceptions are stock market capitalisation and the stock turnover ratio where the second column gives the impact of the overall investor protection index and first column gives the impact of subcomponents of the investor protection index individually. Table 4 shows that there are some - but very few - statistically significant associations. Better legal rights are positively associated with private credit, capital inflows and FDI. However, these relationships are absent for private bank credit,

11 Namely, starting a business; employment regulation; enforcing contracts; getting credit; closing a business; registering property; protecting investors; dealing with licenses; paying taxes and trading across borders. 
Table 3 - Doing Business Indicators and Intermediate Outcomes, Hypothesised Relationships

\begin{tabular}{|c|c|c|}
\hline \multirow{2}{*}{$\begin{array}{l}\text { Indicator } \\
\text { Constraints in starting a business }\end{array}$} & \multicolumn{2}{|c|}{ Intermediate outcome and expected sign of the relationship } \\
\hline & Firm creation (-) & Corruption (+) \\
\hline & Investments (-) & Efficiency of production (-) \\
\hline & Job creation (-) & Tax revenues (-) \\
\hline & Informal economy (+) & \\
\hline \multirow[t]{3}{*}{ Constraints in dealing with licences } & Construction sector (-) & Informal economy (+) \\
\hline & Cheaper offices (-) & Government expenditure $(+)$ \\
\hline & Cheaper warehouses (-) & \\
\hline \multirow[t]{4}{*}{ Rigidities in hiring and firing workers } & Productivity (-) & Adj. to macroeconomic shocks (-) \\
\hline & Informal economy $(+)$ & Adj. to migrant inflows (-) \\
\hline & Business costs $(+)$ & Benefits of trade liberalisation. \\
\hline & Adj. to new technologies (-) & $(-)$ \\
\hline \multirow[t]{3}{*}{ Constraints in registering property } & Property rights (-) & Investment (-) \\
\hline & Property market (-) & Corruption (+) \\
\hline & Credit (-) & Informal economy (+) \\
\hline \multirow[t]{2}{*}{ Ease of getting credit } & Credit (+) & Investment (t) \\
\hline & Non-performing loans (-) & Small enterprises and women $(+)$ \\
\hline \multirow[t]{2}{*}{ Strength of protecting investors } & Equity investments (+) & Investment (+) \\
\hline & Entrepreneurship (+) & Size of stock market $(+)$ \\
\hline \multirow[t]{3}{*}{ Constraints in paying taxes } & Informal economy (+) & Government revenue (-) \\
\hline & Quality of public services (-) & Investment (-) \\
\hline & Corruption (+) & \\
\hline \multirow[t]{2}{*}{ Constraints in trading across borders } & Trade (-) & \\
\hline & Corruption (+) & \\
\hline \multirow[t]{3}{*}{ Constraints in enforcing contracts } & Bank credit (-) & Employment (-) \\
\hline & Interest rates $(+)$ & Government expenditures $(+)$ \\
\hline & Entry of new firms (-) & Integrity of court system (-) \\
\hline \multirow[t]{3}{*}{ Constraints in closing a business } & Investments (-) & Entrepreneurship (-) \\
\hline & Credit (-) & Productivity (-) \\
\hline & Non-performing loans $(+)$ & Job creation (-) \\
\hline
\end{tabular}

Source: Commander and Tinn (2009)

where it might have been expected to be stronger than with the broader measure of private credit. Legal rights are also found not to be associated with higher investment. Better private and public registry coverage appears to be positively associated with higher private credit and private registries with private bank credit when only the 'Getting Credit' indicators are included. However, the significance disappears when all potentially relevant indicators are included in the regression. The same applies for the recovery rate when closing a business and bank credit, as well as for procedures for registering property and enforcing contracts and the broader private credit measure. Better investor protection is associated with higher stock market capitalization but not with stock market liquidity as measured by the stock market turnover ratio. Note that it is hard to argue that the causality of these statistically significant relationships runs from institutions to better credit and stock market development, as the development of these markets will have naturally created a need for better regulation. 
Table 4 - Intermediate Outcomes and Doing Business Indicators

\begin{tabular}{|c|c|c|}
\hline $\begin{array}{l}\text { Left hand side variables and DB } \\
\text { indicators }\end{array}$ & $\begin{array}{l}\text { Regressions with one DB } \\
\text { indicator category included }\end{array}$ & $\begin{array}{l}\text { Regressions with all relevant DB } \\
\text { indicators jointly entered }\end{array}$ \\
\hline \multicolumn{3}{|l|}{ Private credit to GDP } \\
\hline Dealing with licences: procedures & -0.495 & 0.031 \\
\hline Dealing with licences: time & -0.073 & -0.016 \\
\hline Dealing with licences: cost & 0.002 & 0.001 \\
\hline Getting credit: legal rights & $5.020 * *$ & $5.077^{*}$ \\
\hline Getting credit: credit information & -0.034 & 0.720 \\
\hline Getting credit: public registries & $0.631^{*}$ & 0.442 \\
\hline Getting credit: private registries & $0.527^{* *}$ & 0.236 \\
\hline Registering property: procedures & $-3.337 * *$ & -1.386 \\
\hline Registering property: time & -0.079 & -0.063 \\
\hline Registering property: cost & $1.732 * *$ & 1.060 \\
\hline Enforcing contracts: procedures & $-0.729 *$ & -0.090 \\
\hline Enforcing contracts: time & -0.002 & 0.005 \\
\hline Enforcing contracts: cost & 0.077 & 0.032 \\
\hline Closing business: time & 1.475 & -0.372 \\
\hline Closing business: cost & 0.522 & 0.272 \\
\hline Closing business: recovery rate & 1.135 & 0.527 \\
\hline \multicolumn{3}{|l|}{ Private bank credit to GDP } \\
\hline Dealing with licences: procedures & -0.885 & -0.585 \\
\hline Dealing with licences: time & -0.089 & -0.084 \\
\hline Dealing with licences: cost & 0.002 & 0.004 \\
\hline Getting credit: legal rights & 3.443 & 5.122 \\
\hline Getting credit: credit information & 0.229 & 0.555 \\
\hline Getting credit: public registries & 0.675 & 0.530 \\
\hline Getting credit: private registries & $0.488^{* *}$ & 0.247 \\
\hline Registering property: procedures & -1.771 & 0.252 \\
\hline Registering property: time & -0.102 & -0.070 \\
\hline Registering property: cost & $1.648^{*}$ & 1.355 \\
\hline \multicolumn{3}{|l|}{ Private credit to GDP } \\
\hline Enforcing contracts: procedures & -0.691 & -0.031 \\
\hline Enforcing contracts: time & 0.006 & 0.024 \\
\hline Enforcing contracts: cost & 0.098 & 0.186 \\
\hline Closing business: time & 1.533 & -0.404 \\
\hline Closing business: cost & 0.505 & 0.133 \\
\hline Closing business: recovery rate & $1.097^{* *}$ & 0.467 \\
\hline \multicolumn{3}{|l|}{ Construction to GDP } \\
\hline Registering property: procedures & 0.162 & --- \\
\hline Registering property: time & 0.008 & ---- \\
\hline Registering property: cost & -0.007 & ---- \\
\hline \multicolumn{3}{|l|}{ Gross fixed capital formation to GDP } \\
\hline Dealing with licences: procedures & $-0.214 * *$ & -0.171 \\
\hline Dealing with licences: time & -0.008 & -0.011 \\
\hline Dealing with licences: cost & -0.001 & -0.001 \\
\hline Getting credit: legal rights & 0.143 & -0.072 \\
\hline Getting credit: credit information & -0.461 & -0.655 \\
\hline Getting credit: public registries & 0.023 & 0.001 \\
\hline
\end{tabular}


Table 4 - (continued)

\begin{tabular}{|c|c|c|}
\hline $\begin{array}{l}\text { Left hand side variables and DB } \\
\text { indicators }\end{array}$ & $\begin{array}{c}\text { Regressions with one DB } \\
\text { indicator category included }\end{array}$ & $\begin{array}{l}\text { Regressions with all relevant } \\
\text { DB indicators jointly entered }\end{array}$ \\
\hline Getting credit: private registries & -0.027 & -0.027 \\
\hline Registering property: procedures & 0.204 & 0.018 \\
\hline Registering property: time & 0.000 & -0.005 \\
\hline Registering property: cost & -0.089 & 0.039 \\
\hline Enforcing contracts: procedures & $-0.104 *$ & -0.103 \\
\hline Enforcing contracts: time & 0.000 & 0.001 \\
\hline Enforcing contracts: cost & -0.031 & -0.021 \\
\hline Protecting investors: investor protection & -0.201 & -0.035 \\
\hline \multicolumn{3}{|l|}{ Gross private capital flows to GDP } \\
\hline Getting credit: legal rights & $13.920 * *$ & $12.740 * *$ \\
\hline Enforcing contracts: procedures & -0.972 & -0.391 \\
\hline Enforcing contracts: time & -0.025 & -0.013 \\
\hline Enforcing contracts: cost & 0.038 & 0.054 \\
\hline \multicolumn{3}{|l|}{ Net foreign direct investments to GDP } \\
\hline Getting credit: legal rights & $1.037^{* *}$ & $1.034 * *$ \\
\hline Enforcing contracts: procedures & -0.039 & -0.012 \\
\hline Enforcing contracts: time & -0.002 & -0.001 \\
\hline Enforcing contracts: cost & -0.016 & -0.020 \\
\hline \multicolumn{3}{|l|}{ Export to GDP } \\
\hline Trading across borders: documents export & -0.922 & ---- \\
\hline Trading across borders: time export & 0.082 & ---- \\
\hline \multicolumn{3}{|l|}{ Import to GDP } \\
\hline Trading across borders: documents import & -0.509 & ---- \\
\hline Trading across borders: time import & -0.135 & --- \\
\hline \multicolumn{3}{|l|}{ Stock market capitalization to GDP } \\
\hline Protecting investors: disclosure & $7.579 * *$ & ---- \\
\hline Protecting investors: director liability & $14.024 * *$ & --- \\
\hline Protecting investors: shareholder suits & -0.046 & ---- \\
\hline Protecting investors: investor protection & ---- & $21.757^{* *}$ \\
\hline \multicolumn{3}{|l|}{ Stock market turnover ratio } \\
\hline Protecting investors: disclosure & 0.823 & ---- \\
\hline Protecting investors: director liability & 5.643 & ---- \\
\hline Protecting investors: shareholder suits & -2.406 & ---- \\
\hline Protecting investors: investor protection & ---- & 3.417 \\
\hline \multicolumn{3}{|l|}{ Size of informal economy } \\
\hline Starting business: procedures & $0.888^{*}$ & 0.690 \\
\hline Starting business: time & -0.012 & 0.034 \\
\hline Starting business: cost & -0.028 & -0.034 \\
\hline Employing workers: rigidity & 0.059 & 0.087 \\
\hline Employing workers: non-wage cost & 0.069 & 0.005 \\
\hline Employing workers: firing cost & 0.002 & -0.024 \\
\hline Enforcing contracts: procedures & 0.049 & -0.011 \\
\hline Enforcing contracts: time & 0.004 & 0.003 \\
\hline Enforcing contracts: cost & -0.071 & -0.089 \\
\hline \multicolumn{3}{|l|}{ Size of informal economy } \\
\hline Employing workers: rigidity & 0.069 & --- \\
\hline Employing workers: firing cost & 0.016 & ---- \\
\hline
\end{tabular}

Note: the coefficients with * indicate statistical significance at $10 \%$ level and with ${ }^{* *}$ at $5 \%$ significance level. All regressions estimates with OLS. Data on Doing Business indicators available for 2003. 
Other relationships appear even weaker. For example, there are no significant and predictably signed associations with registering property indicators and construction, export and import with the trading across borders indicators, informal economy and starting business, employing workers and enforcing contracts and unemployment with employment indicators. Investment is unrelated to most doing Business indicators, while there is a weak association with procedures to deal with licences and enforcing contracts.

\section{Institutions and Performance at Firm Level}

Moving beyond country level aggregates a parallel strand of analysis is to relate firm level measures of performance to institutional measures. In this section, we use firm level data collected by the World Bank using 135 surveys in over 70 countries between 1999 and 2005. These data include the Productivity and Investment Climate Surveys as well as the Business Environment and Enterprise Performance (BEEPS) surveys that cover the transition countries. While these data have themselves collected measures of institutions, they also contain information on a common measure of performance, namely on the level of, and change in, sales per worker or labour productivity. It is this measure of performance that we use initially and relate to the Doing Business indicators. Later using the BEEPS, we also bring in the surveys own institutional measures.

Using the Doing Business indicators has the problem of limited data points and potential reverse causality. Yet, using firm level responses for the left-hand side performance measure and Doing Business indicators as explanatory variables - where such indicators as averages could be viewed as exogenous to the firm - may be an appropriate identification strategy. However, we are forced to use past measures of performance against current measures of constraints. In that sense, the estimate is clearly mis-specified. However, given that we would not expect too many changes in the Doing Business indicators over the reference period, this may not be that serious a problem. Moreover, at this point the aim of the exercise has been less to deal with possible issues of biased estimates, than to see whether indeed there is any simple association between performance and the institutional indicators.

Table 5 reports the results. Estimation is by Ordinary Least Squares with controls for industry, firm size (small, medium, large), majority ownership (domestic private, foreign, state), age (less than 5, 5 to 10 and more than 10 years) and the shares of workers with secondary education in the firm (the baseline case). We additionally run the regressions by adding lagged log PPP adjusted GDP per capita to control for the general development level of the country. ${ }^{12}$ The Doing Business indicators are individually entered and

12 Adding lagged GDP per capita serves as a proxy for features of the business environ- 
in the last two columns, jointly.

Table 5 - Growth in Firm Level Sales Per Worker and Doing Business Indicators

\begin{tabular}{|c|c|c|c|c|}
\hline \multirow{2}{*}{ Controls } & \multicolumn{2}{|r|}{ Individually entered } & \multicolumn{2}{|r|}{ Jointly entered } \\
\hline & "Base" & "Base" \& GDP per capita & "Base" & Base" \& GDP per capita \\
\hline \multicolumn{5}{|l|}{ All countries } \\
\hline Starting business: time & --- & --- & -0.112 & -0.124 \\
\hline Dealing with licences: time & ---- & ---- & 0.043 & 0.037 \\
\hline Employing workers: rigidity employment & --- & --- & --- & --- \\
\hline Registering property: time & -0.039 & -0.053 & ---- & --- \\
\hline Getting credit: legal rights index & 1.178 & 1.158 & ---- & ---- \\
\hline Protecting investors: investor protection & --- & --- & ---- & --- \\
\hline Paying taxes: time & 0.002 & 0.002 & --- & 0.006 \\
\hline Trading across borders: time export & 0.282 & 0.309 & 0.442 & 0.399 \\
\hline Enforcing contracts: time & -0.011 & -0.012 & -0.014 & -0.013 \\
\hline Closing business: time & --- & --- & --- & --- \\
\hline \multicolumn{5}{|l|}{ High and upper middle income countries } \\
\hline Starting business: time & -0.260 & -0.237 & & \\
\hline Dealing with licences: time & 0.128 & 0.113 & 0.280 & 0.433 \\
\hline Employing workers: rigidity employment & 0.454 & 0.406 & 0.380 & \\
\hline Registering property: time & -0.420 & --- & & \\
\hline Getting credit: legal rights index & --- & --- & & \\
\hline Protecting investors: investor protection & ---- & --- & & \\
\hline Paying taxes: time & -0.033 & -0.028 & 0.089 & 0.103 \\
\hline Trading across borders: time export & -0.570 & -0.457 & & \\
\hline Enforcing contracts: time & -0.051 & -0.044 & --- & --- \\
\hline Closing business: time & ---- & ---- & & \\
\hline \multicolumn{5}{|l|}{ Lower middle income countries } \\
\hline Starting business: time & 0.088 & ---- & 0.364 & ---- \\
\hline Dealing with licences: time & --- & --- & --- & --- \\
\hline Employing workers: rigidity employment & -0.185 & ---- & ---- & --- \\
\hline Registering property: time & -0.036 & --- & --- & --- \\
\hline Getting credit: legal rights index & ---- & --- & ---- & --- \\
\hline Protecting investors: investor protection & 2.992 & --- & -14.038 & -22.918 \\
\hline Paying taxes: time & 0.005 & ---- & --- & --- \\
\hline Trading across borders: time export & -0.611 & -0.332 & -2.374 & -2.703 \\
\hline Enforcing contracts: time & -0.010 & --- & ---- & --- \\
\hline Closing business: time & --- & ---- & -6.385 & -8.815 \\
\hline \multicolumn{5}{|l|}{ Low income countries } \\
\hline Starting business: time & --- & --- & --- & 0.488 \\
\hline Dealing with licences: time & -0.039 & -0.056 & 0.245 & -0.168 \\
\hline Employing workers: rigidity employment & -0.202 & -0.235 & 0.375 & 0.951 \\
\hline Registering property: time & --- & -0.063 & 0.436 & -0.333 \\
\hline Getting credit: legal rights index & 3.261 & 2.953 & 17.292 & \\
\hline Protecting investors: investor protection & --- & -2.015 & & \\
\hline Paying taxes: time & --- & --- & 0.108 & -0.181 \\
\hline Trading across borders: time export & 0.697 & --- & 2.150 & --- \\
\hline Enforcing contracts: time & -0.009 & -0.007 & ---- & -0.083 \\
\hline Closing business: time & --- & --- & --- & -12.367 \\
\hline
\end{tabular}

Note: "Base" controls are the shares of labour with secondary and higher education and industry, size and age dummies The table reports only coefficients that are significant at $95 \%$ and bold indicates significance and "correct" sign. All regressions estimated with OLS. Data on Doing Business indicators covers 2003.

The performance equations are separately estimated for the different income groups. Coefficients with the predicted sign and significant at a $5 \%$ or higher level are indicated in bold type.

While there is some evidence that when entered individually some of the Doing Business indicators have the predicted sign and significance, it is striking that this is mainly true for the high and upper middle income group. Further, a number of coefficients lose significance when the controls for income per capita are included. This is particularly true for the lower ment that are not incorporated in the Doing Business indicators. Obvious problems from potential endogeneity arise. 
middle income countries. Turning to the case where the indicators are entered jointly, variables often switch signs or lose significance altogether. A number of the signs are perverse. The estimates including the income per capita control perform better than the base specification for the low income group 13

What can be concluded from this set of estimations using the large World Bank firm survey dataset? The most obvious finding is that the Doing Business constraints are relatively weak and unstable predictors of firm level performance. Further, we have also experimented with relating other outcome measures selectively to the Doing Business indicators. For example, we used the firm dataset to relate a variable summarising the share of loans given as collateral to the getting credit and enforcing contracts variables from Doing Business. We have also related whether a firm has developed a new product line or introduced new technology to the getting credit measures, as well as the protecting investor variables. This was done one at a time and then jointly. In the great majority of instances, we found no significant association and, in many cases, the sign switched when shifting from individual to joint estimation. 14

So far, the analysis has simply extracted the performance measure from the survey evidence. At this point, we shift from relying on the Doing Business institutional measures to those generated by the surveys themselves and by the BEEPS, in particular. This dataset covers 26 transition economies in Europe and the former Soviet Union with four full rounds of sampling in 1999, 2002, 2005 and 2009 of which the last three are used in our analysis. The 2002 round of the BEEPS surveyed some 6,100 firms, the 2005 round covered nearly 9,100 firms and the 2009 round over 7,800 firms in the same countries. Around 90 per cent of the BEEPS sample in both years comprised small and medium enterprises. Most firms in the samples had been privatised or were always private. The average firm size in employment ranged between 105 and 143, although median employment was considerably lower at around 30. On average, exports comprised around $10 \%$ of total sales. With respect to the business environment, each firm's top manager was asked to provide their perception of the constraints ranking from 1-4. Table 6 indicates average scores in the three years. Tax rates, corruption and cost of financing were viewed as significant obstacles in all periods with the average score being in the range of 2.3-2.7. However, there was large variation in mean values across perceived constraints - standard deviations were large, although declining in 2009.

\footnotetext{
13 Note that when adding alternative measures of the business environment, such as, the 'Rule of Law' measure in Kaufmann et al. (2006), the explanatory power of the Doing Business indicators decreased further.

14 Results available on request.
} 


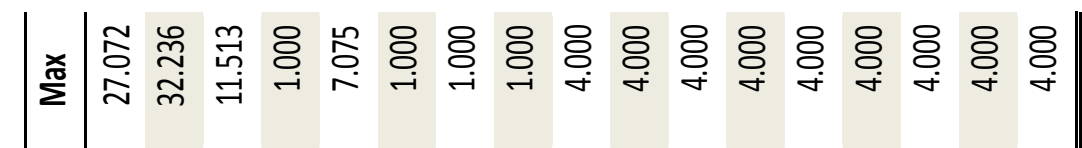

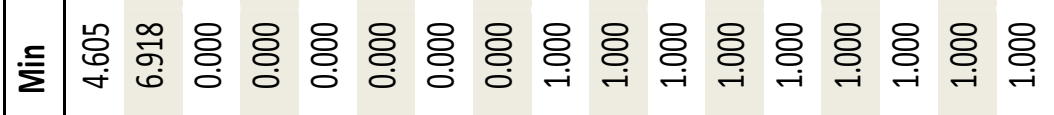

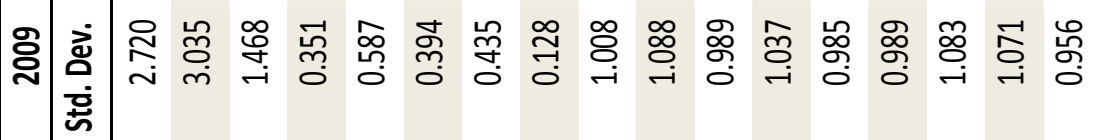

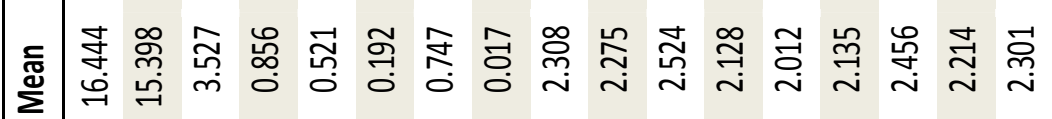

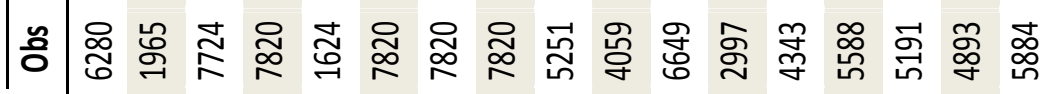

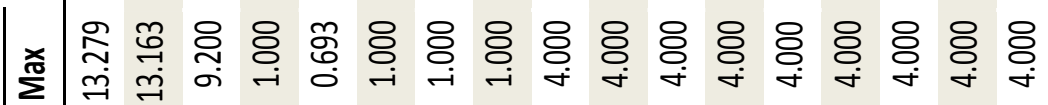

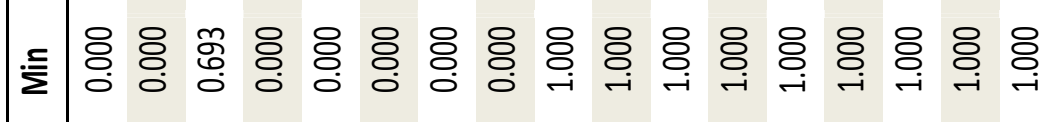

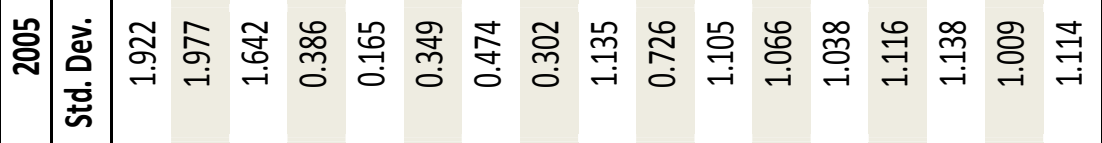

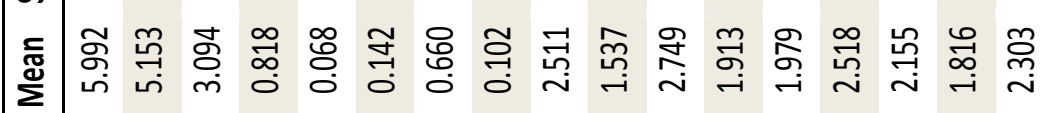

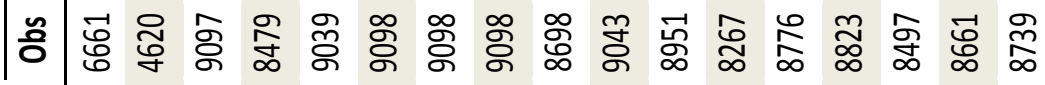

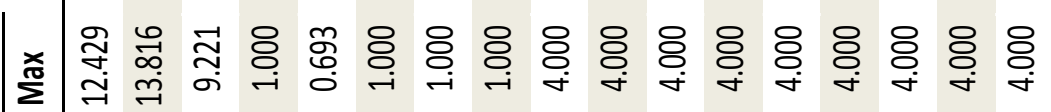

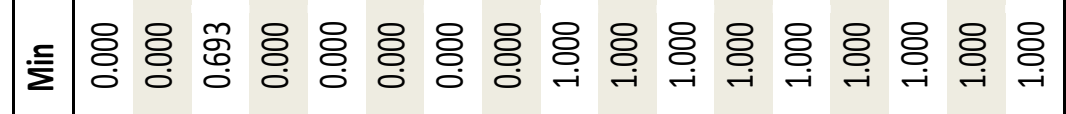

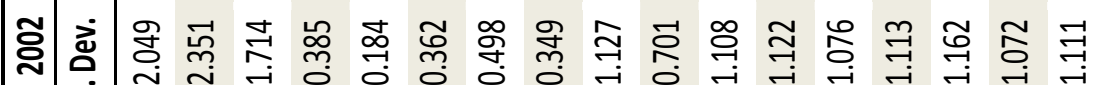

离

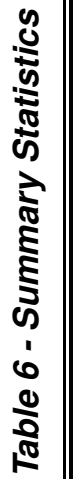

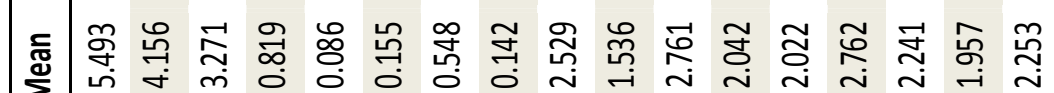

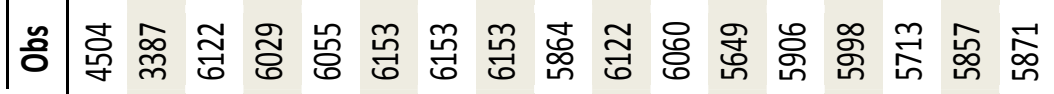


Our approach is to analyze the determinants of the efficiency with which the firms generate sales revenue from inputs. $\sqrt{15}$ This is done by estimating an augmented Cobb Douglas revenue function where efficiency is allowed to vary across institutional and structural variables, industries and countries. The aim, in particular, is to see whether the constraints variables help to explain differences in efficiency. In keeping with much of the literature, we start by using OLS without controlling for country and sector fixed effects. A dummy for the type of privatization is introduced. The constraints variables were based on responses by all other firms in a given industry in each country and year. Without the sector and country controls and in common with some of the existing literature, we find that when entered individually many, if not the majority, of the constraints terms enter significantly and predictably, i.e., negatively signed. However, entering these terms individually raises an obvious issue of omitted variables, so we have re-estimated entering the constraints terms jointly. When that is done, a number of constraints variables lose significance in all cross-sections, ${ }^{16}$ In 2002 and 2005 the majority of constraints remain significant, while in 2009 only two stay significant when entered jointly. The constraints variables that remain significant vary across each of the years.

Estimating without controlling for sector and country is also likely to lead to biased estimates. Tables $7 \mathrm{a}, 7 \mathrm{~b}$ and $7 \mathrm{c}$ report the results of estimating when these controls are applied. Using the 2002 data (Table 7a) it can be seen that when entered separately four of the constraints terms are signed significantly and negatively, as would be predicted. When entered all together only two of the variables are significant while one - customs and foreign trade regulations - is positive and significant. For the 2005 sample (Table $7 \mathrm{~b}$ ) only one of the constraints terms is negatively signed and significant when entered either individually or jointly. In some instances, constraints enter positively and significantly. Finally, in the 2009 cross-section (Table 7c) none of the individually entered constraints has the predicted sign and significance; in the joint estimation that was true only for the cost of financing.

There are, however, obvious drawbacks with OLS, not least potential endogeneity or selection issues relating to some of the explanatory variables. To counter this, we employ instrumental variables. Unfortunately, this is only possible for the 2002 and 2005 rounds as changes in the survey design and reference periods collected in the 2009 round meant that we were unable to apply a common set of instruments. Using the 2002 and 2005 cross-sections, we adopt a two stage approach where the first stage involves estimation in levels with revenue being related to factors, ownership, competition and export exposure.

15 This is the broad approach taken in Commander and Svejnar (2011).
16 These results are available on request from the authors. 


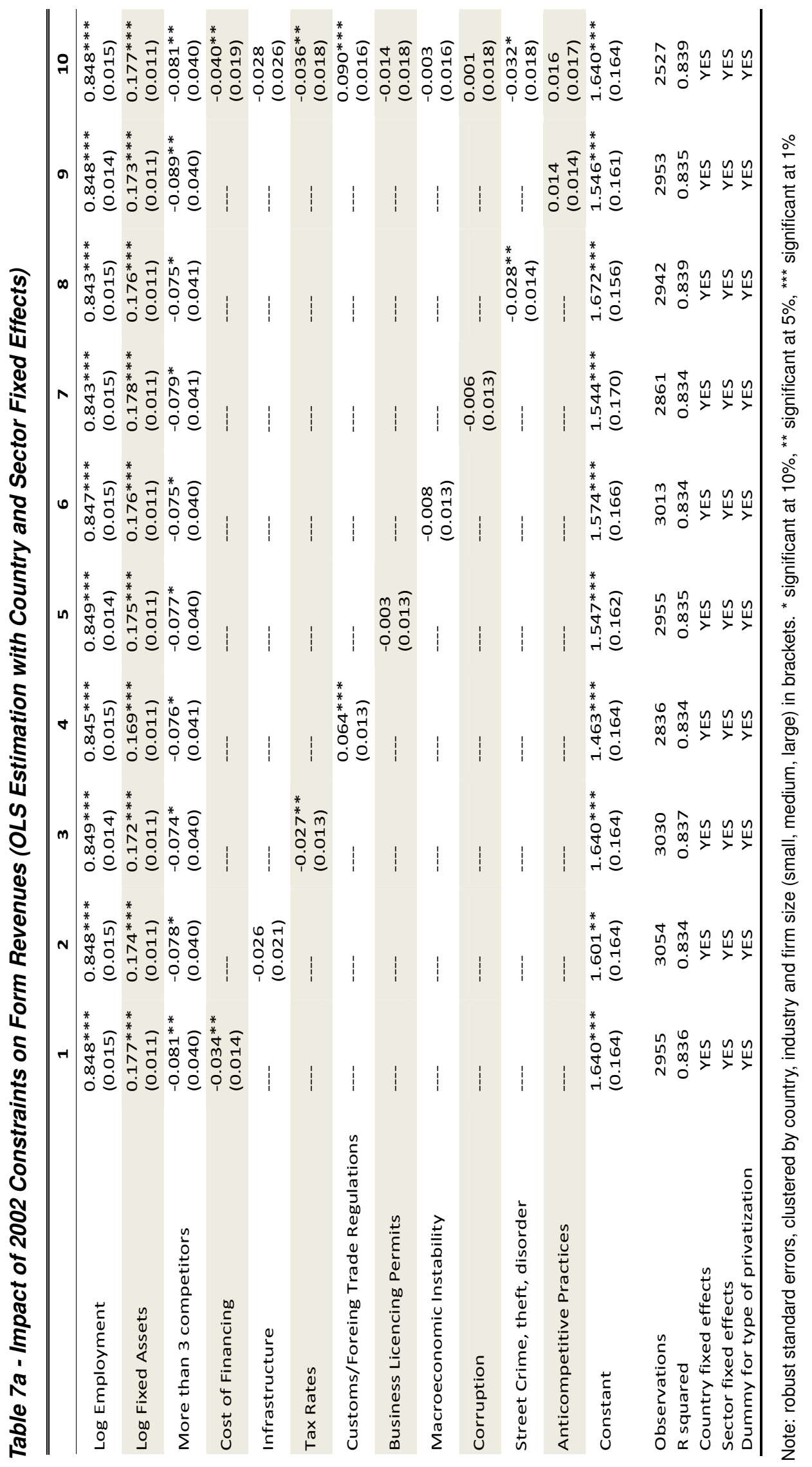

http://www.rei.unipg.it/rei/article/view/33 


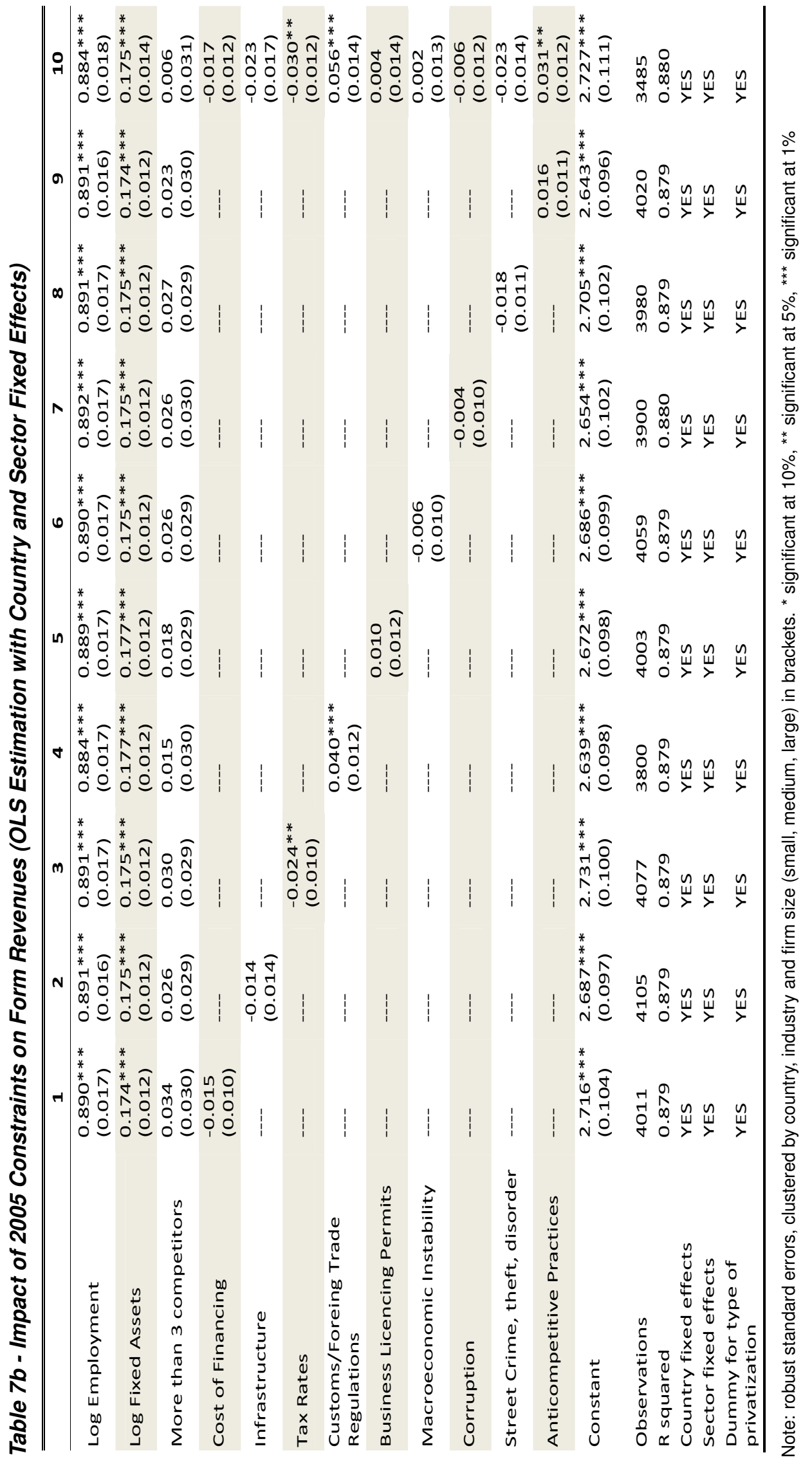




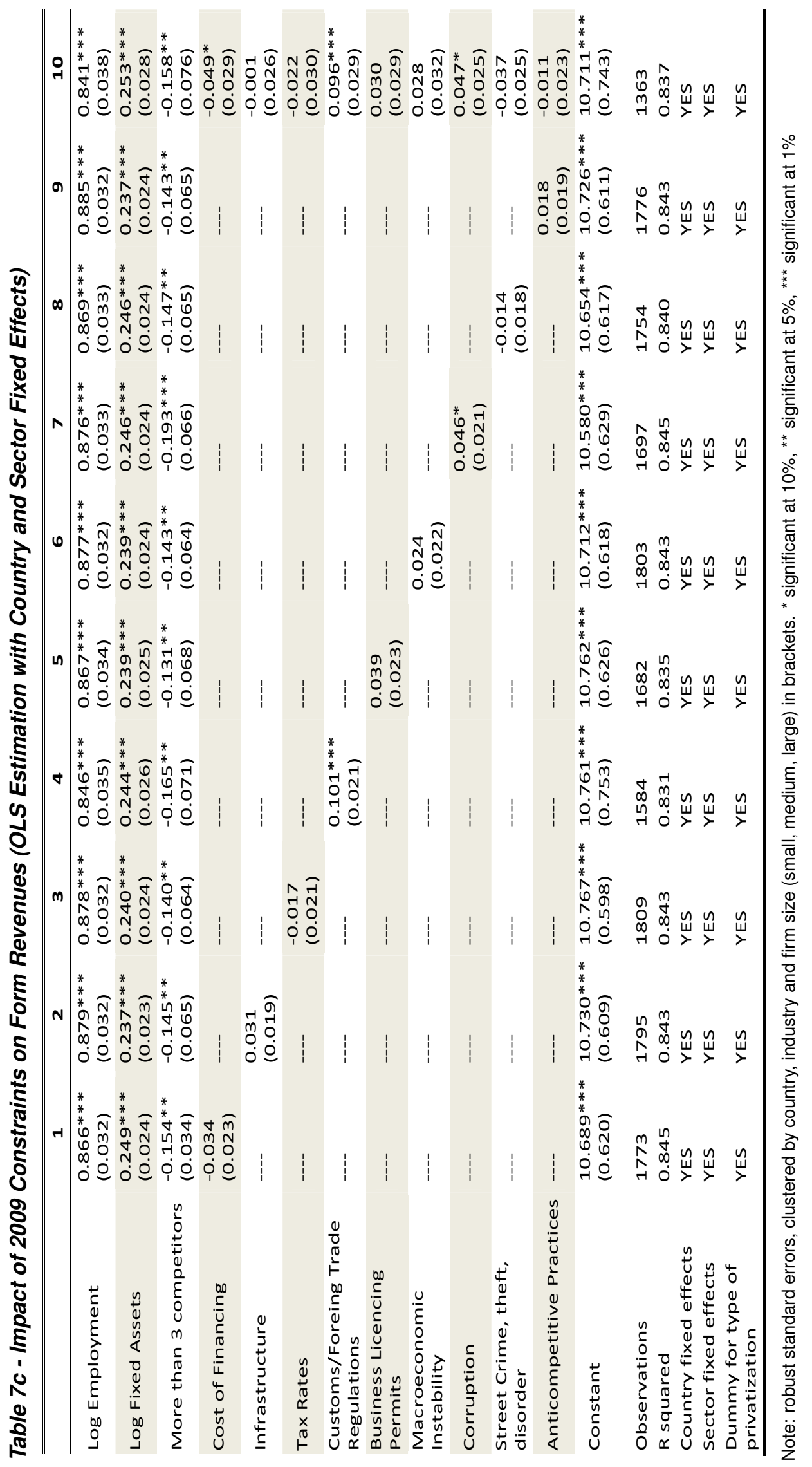

http://www.rei.unipg.it/rei/article/view/33 
The IVs used for the levels of the capital and labour inputs, categories of ownership and the export orientation of the firm were the age of the firm, the skill ratio interacted with the three main regions covered by the data, the skill ratio interacted with firm age and the three regions, a three-year lag of full time employees, the change in fixed assets in the preceding three years, and the change in the export share over the preceding three years. These IVs were found to be good predictors of all the potentially endogenous variables and passed the J over-identification test (see Table 8a and 8b). The extent of competition in the firm's product market was taken to be exogenous.

The second stage was to consider directly the impact of business environment constraints on firm performance. An average value of each constraint was used. When entered individually, only one of the constraints entered negatively and significantly for 2002 and 2005 and these were actually different constraints across the two years. When entered jointly only the infrastructure constraint was negative and significant in 2005 (Table $8 b)$. In short, in a specification with instrumentation and including country and sector fixed effects almost all of the constraint terms were insignificant and/or incorrectly signed ${ }^{17}$

In sum, applying a careful analysis to a large and well-used dataset the BEEPs - we find that the measures of the business/institutional environment do not support a strong, negative relationship between constraints and firm performance.

17 Commander and Svejnar (2011) merged the BEEPS firm-level data with the Doing Business indicators. When entering the Doing Business indicators individually into similar IV regressions using pooled data and in a specification with country, industry and year fixed effects, only four of the twelve indicators generated the expected negative coefficients. In the IV regressions without fixed effects, only two of the twelve indicators had negative effects. Moreover, the indicators with the negative coefficients were not the same across specifications. 


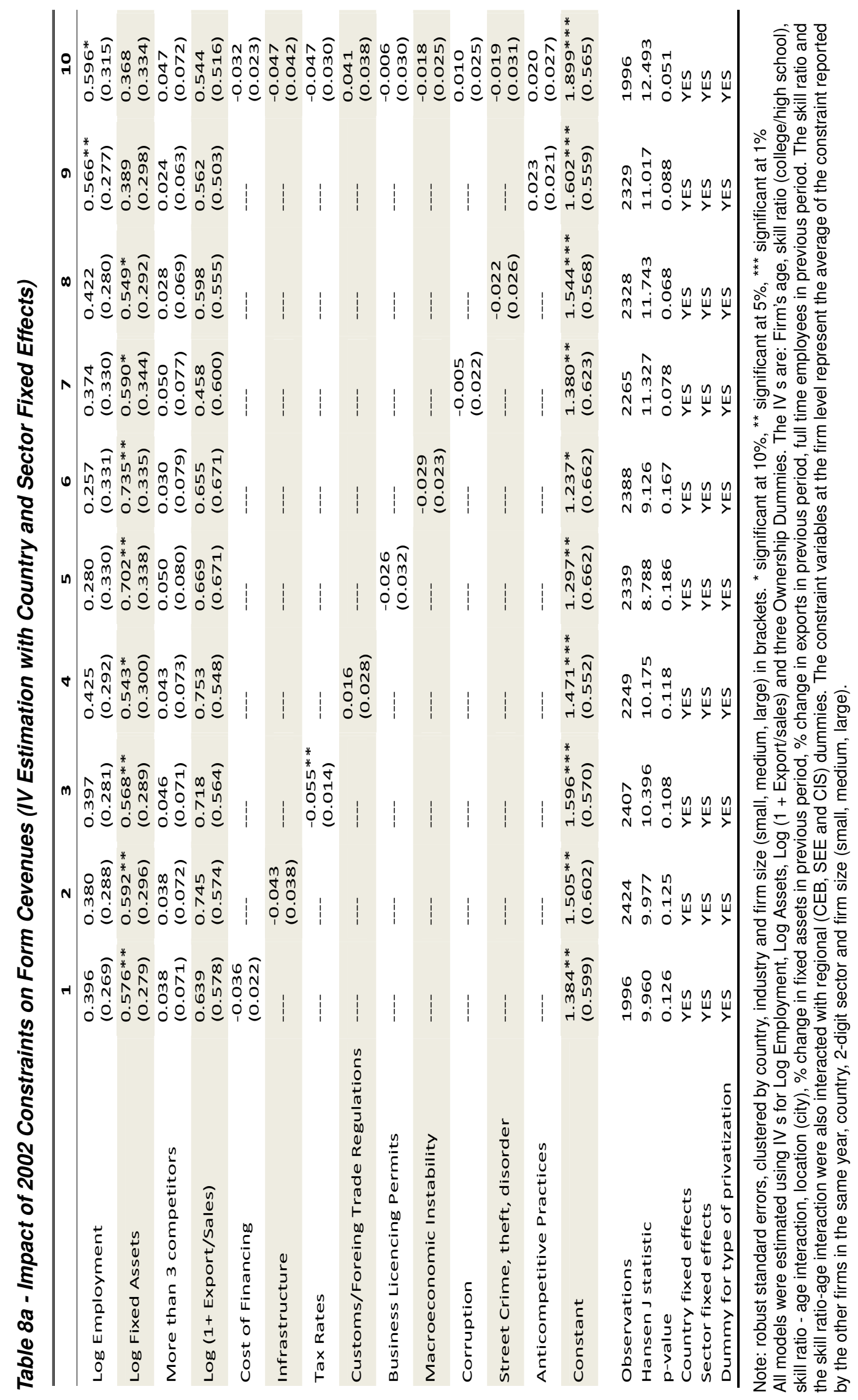

http://www.rei.unipg.it/rei/article/view/33 


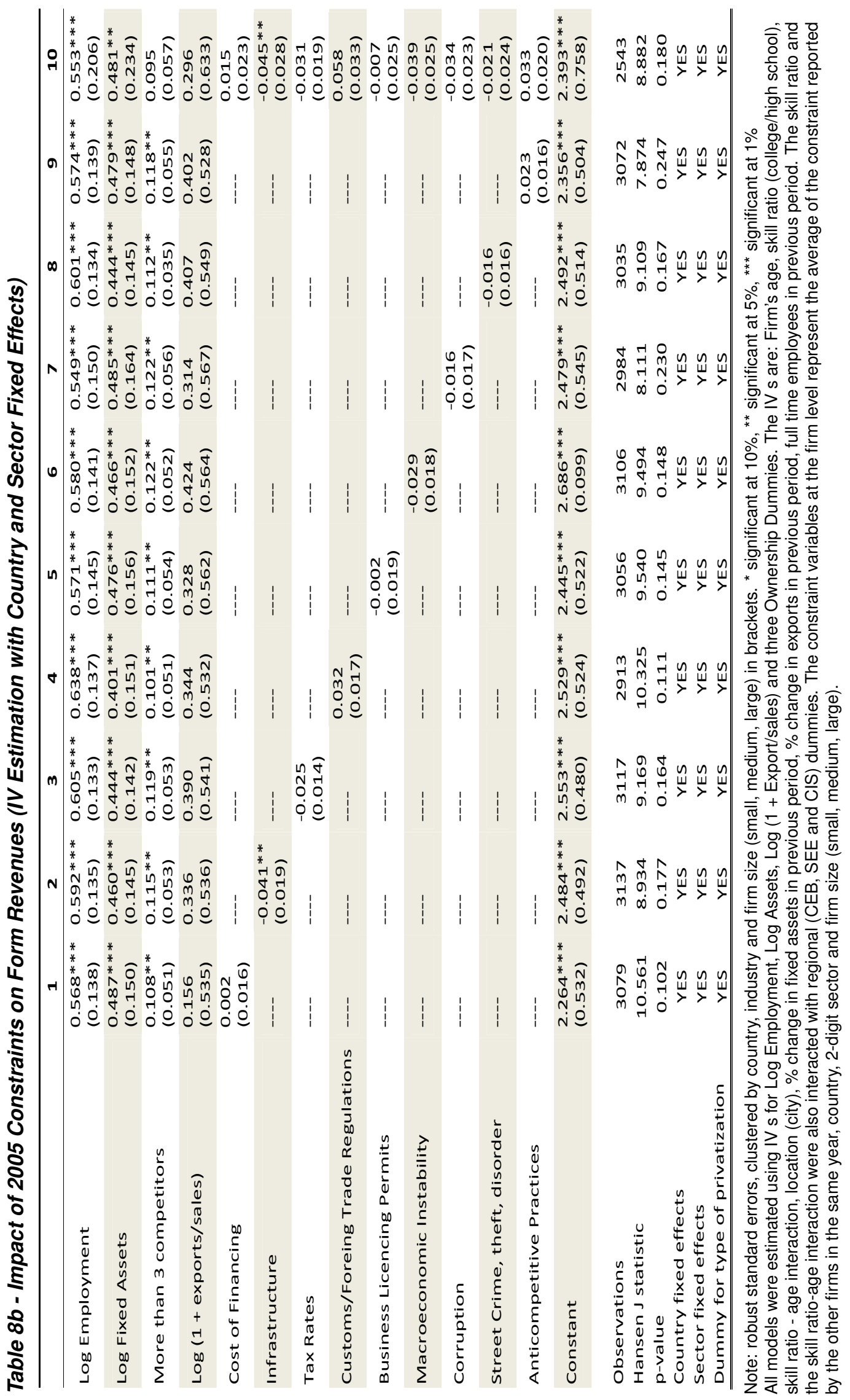




\section{Why Is So Little Explained?}

\subsection{Political Systems and Performance}

Limitations in measurement appear to be part of the answer. Most measures of political systems construct indices, commonly on a $0-10$ scale or just binary, based on procedures and laws. These narrow procedural definitions obviously ignore any outcome dimensions, yet there are indicators, such as accountability, equality and/or civil rights, that are likely to be important in explaining performance. Lindert (2002) has argued that taxonomies of political regimes commonly ignore large differences in the share of adults who have any real voice. For example, Polity IVs' index rates the USA as a full democracy pre-1939, yet this skirts the fact that blacks were effectively disenfranchised and certainly devoid of real political voice. Further criticism has focused on the way in which the main measures classify regimes on the basis of the central government alone. Yet, particularly in large countries, decentralized power and decision making has become increasingly important. Most the institutional indexes used are ordinal, thereby ranking countries on some criterion without specifying the degree of difference between countries. As such, for the purpose of growth regressions, ordinal indices need to be transformed into cardinal ones (a point made by Barro, 1996). Yet, there is no reason to pre-suppose that such a transformation should be onefor-one: for instance, the difference in the quality of the judiciary in the USA and South Africa may be much smaller than that between South Africa and Zaire, even though the same differential is measured on an ordinal scale of 1 to 10 . In principle, such nonlinearities can be addressed by including nonlinear terms for the independent variable. A further criticism concerns the way in which different components of many of the indexes are aggregated (Aron, 2000). Typically, components are simply added up or averaged with the same weights. With many components, factor analysis that aggregates components with unknown weights would be superior.

While measurement is likely to be part of the problem, it is also clear that there can be different, and sometimes opposing, mechanisms through which democracy has an impact on growth. For example, Tavares and Wacziarg (2001) examine the importance of different transmission mechanisms and find that democracy can foster growth by raising educational attainments but that, under certain assumptions, it can act differently on growth by affecting the rate of physical capital accumulation. Alesina et al. (1996) focus on political instability and its consequences for efficiency and growth. They do not explicitly deal with the issue of whether instability is a product of a particular type of political system, but are able to show that in countries where instability is greater, growth tends to be lower but that there is no significant difference between authoritarian and democratic 
regimes. Other papers cited above - notably those by Mancur Olson - have also suggested that it may be factors such as longevity and credibility of governments that may best explain performance. And while credibility and stability may tend to be greater under democracy, this has not necessarily been the case. With similar ambiguity, Acemoglu (2007) argues that higher democracy tends to be good for growth because it reduces the extent to which existing oligarchies can prevent entry by potential competitors. On the other hand, democracy also tends to lead to higher tax rates in equilibrium, which in turn tends to discourage innovation, ceteris paribus. In short, the inability to bolt down a tight, robust relationship between political system and performance may be as much to do with the inability of such an approach to pin down the underlying complexities and non-linearities. Expressed differently, we are probably asking far too much.

\subsection{Country and Firm Performance}

Our analysis has found that neither at country nor firm level do widely used measures of the business environment appear to have significant explanatory power when relating constraints to performance, particularly when paying careful attention to issues of endogeneity. As in the discussion of political systems, potential explanations have several dimensions and can, perhaps, best be grouped into four broad categories. The first is that the various indicators may simply be mis-measured. The second is that the indicators may be incomplete and/or too specific. The third is that the underlying relationships may be more complex and the fourth is that the identification strategy may be flawed.

With respect to measurement, a starting point is to ask whether firm and country level measures of obstacles actually give broadly consistent responses. Commander and Tinn (2009) use firm level evidence from the World Bank Enterprise Surveys dataset containing over 30,000 firm level observations for at least 75 countries relating to the period from 1999-2006 and relate responses in these firm level surveys to the Doing Business indicators that are their closest match. They find that there is no tight association between firm level survey responses and the Doing Business measures. To understand why this might be the case, it is useful to look in more detail at the firm level evidence from the surveys. What emerges is that there is large variation in responses, particularly with respect to variation within countries. Further, there is more variation within-industry than betweenindustry, ${ }^{18}$ suggesting much variation in subjective responses. Given that the attributes of individual respondents' cannot be controlled for, this variation is hard to explain. Clearly, subjective evaluations raise questions regarding possible bias (Bertrand and Mullainathan, 2001). What is less clear is whether one or other of the measures is superior in the measurement of

18 There are no obvious patterns when controlling for the size of firm or ownership. 
constraints. At this point, all that can be said is that there are major discrepancies between the two approaches that are difficult to understand, let alone explain. Any mis-measurement might come from either source. ${ }^{19}$

With respect to the country level indicators in Doing Business, the objective of looking at an average representative firm is likely to be problematic. First, there is the issue of how a representative business is defined. Second, focusing on an average firm obviously ignores heterogeneity among firms as well as sectoral specialisation in a country. The higher correlation of the Doing Business indicators observed in high income countries might suggest that the templates are best designed for a representative firm in a high income country. If firms in less developed countries are engaged in substantially different production activities, the constraints they face are likely to be very different.

Similar sample selection issues are likely to affect the responses of firms more generally. If there are many obstacles in the business environment, only agents with the best entrepreneurial and/or managerial talent may be active. Further, it is unclear what entrepreneurial or managerial talent actually means in a poor business environment. For example, it may be that these entrepreneurs have the best ability for dealing with corruption rather than being the most dynamic in other more productive areas. Such issues are likely to create bias in firm responses.

Both the Doing Business indicators and firm level responses are ultimately subjective. Responses can be affected by the mood and personality of the respondent as well as by respondents adapting to the business environment. While the first effect is likely to average out in the firm level surveys, it does not necessarily average out in a small number of expert opinions, as in Doing Business. To the extent that questions in Doing Business are more objective by trying to measure constraints more specifically - such as the time to enforce contracts - they may suffer from less possible bias than firm level surveys. The issue of adaptation is clearly a problem when evaluating the business environment using firm level subjective responses. In this instance, it will not average out irrespective of the number of responses.

Additional explanations fer the lack of explanatory power could be that the variables and indicators that are collected are too specific. Take the example of credit and enforcing contracts. The theoretical literature often models this as the probability of avoiding repayment to the creditor (for example, Hart and Moore, 1994; Marimon and Quadrini, 2006; Aghion et al., 2003). There is no direct measure of this in the Doing Business indicators,

19 Commander and Tinn (2009) also examine in detail the properties of the Doing Business indicators. Looking at the correlation between the different indicators collected in Doing Business, they find almost no correlation. While this absence could support the view that each is providing unique information, it is hard intuitively to understand why this is the case. One possibility is that the indicators are measuring unrelated phenomena, although this seems implausible. It also implies that a change in one indicator would not necessarily have an impact on others. 
while there are several proxies such as the time, procedures and cost of enforcing contracts. There are also important variables and indicators missing in both firm and country level surveys. For example, R\&D and technology adoption are likely to be major sources of growth and incentives to innovate are likely to be affected by intellectual property rights (Parente and Prescott, 1994). The incompleteness of the existing measures - as with Doing Business - is likely to be a problem.

There is also the broader question as to the validity of the assumption of a monotonic relationship between country level indicators and economic performance. For example, the correlation of the Doing Business indicators with GDP and with several intermediate outcomes appears to decline with income (Commander and Tinn, 2009). This result is not surprising. For example, investor protection is likely to be important in countries that have formal equity markets. In the absence of these markets, differences is minority shareholder protection are unlikely to affect performance. Another example concerns the substantial differences in the availability of skilled labour among countries. The technology that is appropriate in countries that are abundant in skilled labour may not be appropriate in countries that are not (Acemoglu, 2002). As a result, the constraints to productive activity in high versus low income countries may be different depending on the availability of skilled labour. This suggests the presence of thresholds of income per capita or other indicators, such as labour force or size of equity markets, at which constraints will matter or not.

Finally, there is the issue of the identification strategy. In the context of firm level evidence, Carlin et al. (2006) argue that the parameter estimates from an equation relating a measure of performance to particular constraints can be biased for several reasons. The first is that many of the measures of constraints that have been collected may in fact be more in the nature of public goods that are an input into private production. As such, the issue of the endogeneity of public good supply will exist, as better performing countries will generally have better levels of supply. Second, with respect to the demand for public goods, better performing firms will tend to demand better public goods provision. In other words, there may be a problem of reverse causality. ${ }^{20}$ However, when an instrumental variables approach has been used in order to avoid these pitfalls, we have been unable to find robust evidence of constraints having an impact on performance.

\section{Conclusion}

A broad consensus appears now to exist concerning the importance of institutions for economic performance. Our paper has taken a close look at this proposition by focusing on three, related questions. The first con-

20 More generally, in firm surveys the information on performance and constraints are raised simultaneously which can create problems. 
cerned whether the type of political system, and its associated institutions, tends to affect performance. The simple conjecture, drawn from a significant literature, was that democracy in particular has features that should be encouraging for performance, even if that underlying relationship was not linear. This was addressed using several sets of country level measures of political institutions and through use of leading edge GMM estimation. The second concerned the impact of institutions connected to the investment and business environment on the performance of countries, irrespective of their political configuration. In particular, this part of the analysis focused on a widely cited measure of the business environment that covers 175 countries; the World Bank's Doing Business. The third question was to ask whether the evidence could robustly support the broad proposition that the performance of firms' could be materially influenced by the business environment. This required, above all, econometric implementation able to address the pervasive problems of endogeneity and unobserved heterogeneity.

The results reported in the paper are ambiguous, if not hostile, to the default proposition of institutions affecting performance. In the case of political institutions, none of the explanatory variables was significant. For country level analysis we were limited by an absence of an adequate number of observations on time. But the analysis that we were able to implement indicates that no robust conclusions can be drawn. In the case of firm level analysis, using a large two-period dataset on twenty six transition countries - countries whose initial conditions comprised largely similar institutional formats - we were unable to find any strong relationship between revenues and the institutional constraints. Country effects that captured other sources of cross-country heterogeneity were found to matter for performance.

Finally, the paper addressed why these exercises have yielded a relatively meagre harvest, at least when held up against the prevailing orthodoxy. Put simply, it would appear that issues of measurement - including bias arising from subjective evaluation - mis-specification, complexity and non-linearity are all relevant. 


\section{References}

Acemoglu, D. (2002). Technical Change, Inequality and the Labor Market. Journal of Economic Literature, 40(1). 7â72. doi:10.1257/0022051026976

Acemoglu, D. (2007). Oligarchic Versus Democratic Societies. Journal of the European Economic Association, 6(1). 1-44. doi:10.1162/JEEA.2008.6.1.1

Aghion, P., Alessina, A., \& Trebbi, F. (2007). Democracy, Technology and Growth.Unpublished manuscript, Harvard University.

Aghion, P., Howitt P., \& Mayer-Foulkes, D. (2003). The Effect of Financial Development on Convergence: Theory and Evidence. Unpublished manuscript, Harvard University.

Alesina, A., Oezler, S., Roubini, N., \& Swagel, P. (1996). Political Instability and Economic Growth. Journal of Economic Growth, 1(2). 189-211. doi:10.1007/BF00138862

Aron, J. (2000). Growth and Institutions: a Review of the Evidence. The World Bank Research Observer, 15(1). 99-135.

Barro, R.J. (1996). Democracy and Growth. Journal of Economic Growth, 1(1). 1-27. doi:10.1007/BF00163340

Barro, R.J. (1997). Determinants of Economic Growth: A Cross-Country Empirical Study. Cambridge, MA: MIT Press.

Barro, R.J., \& Lee, J.-W. (1993). Losers and Winners in Economic Growth. (Working Paper No. 4341). Retrieved from Nationl Bureau of Economic Research website: http://www.nber.org/papers/w4341.pdf

Bertrand, M., \& Mullainathan, S. (2001). Do People Mean What They Say? Implications for Subjective Survey Data. American Economic Review, 91(2). 67-72. http:/ /www.jstor.org/stable/2677735

Botero, J.C., Djankov, S., La Porta, R., Lopez de Silanes, F., A., \& Shleifer, A. (2004). The Regulation of Labor. Quarterly Journal of Economics, 119(4). 1339-1382. doi:10.1162/0033553042476215

Carlin, W., Schaffer, M.E., \& Seabright, P. (2006). Where are the Real Bottlenecks? A Lagrangian Approach to Identifying Constraints on Growth from Subjective Survey Data, (CERT Discussion Papers n. 0604). Retrieved from: http://www.sml.hw.ac.uk/downloads/cert/wpa/2006/dp0604.pdf

Cheibub, J.A., Gandhi, J. \& Vreeland, J.R. (2009). Democracy and Dictatorship Revisited. Public Choice, 143(1-2). 67-101. doi:10.1007/s11127-0099491-2 
Comeau, L. (2003). Democracy and Growth: A Relationship Revisited. Eastern Economic Journal, 29(1).1-21.

Commander, S., \& Svejnar, J. (2011). Do Institutions, Ownership, Exporting and Competition Explain Firm Performance? Review of Economics and Statistics. Forthcoming.

Commander, S., \& Tinn, K. (2009). Evaluating Doing Business. Paper prepared for the World Bank, IEG Working Paper.

De Haan, J., \& Siermann, C.L.J. (1995). A Sensitivity Analysis of the Impact of Democracy on Economic Growth. Empirical Economics, 20(2). 197-215. doi:10.1007/BF01205435

De Soto, H. (2000). The Mystery of Capital: Why Capitalism Triumphs in the West and Fails Everywhere Else. New York: Basic Books.

Dollar, D., Hallward-Driemeier, M., \& Mengistae, T. (2005). Investment Climate and International Integration. (Policy Research Working Paper $\mathrm{n}$. 3323). Washington, DC: The World Bank.

Fernandez, R., \& Rodrik, D. (1991). Resistance to Reform: Status Quo Bias in the Presence of Individual-Specific Uncertainty. American Economic Review, 81(5). 1146-55.

Grier, K., \& Tullock, G. (1989). An Empirical Analysis of Cross-National Economic Growth, 1951-1980. Journal of Monetary Economics, 24(2). 259-276. doi:10.1016/0304-3932(89)90006-8

Hart, O., \& Moore, J. (1998). Default and Renegotiation: A Dynamic Model of Debt. The Quarterly Journal of Economics, 113(1). 1-41. doi:10.1162/003355398555496

Kaufmann, D., Kraay, A., \& Mastruzzi, M. (2006). Governance Matters V: Governance Indicators for 1996-2005. (Working Paper n. 4012). Washington, DC: The World Bank. doi:10.1596/1813-9450-4012

Kormandi, R.C., \& Meguire, P.G. (1985). Macroeconomic Determinants of Growth: Cross-Country Evidence. Journal of Monetary Economics, 16(2). 141163. doi:10.1016/0304-3932(85)90027-3

Levine, R., \& Renelt, D. (1992). A Sensitivity Analysis of Cross-Country Growth Regressions. American Economic Review, 82(4), 942-963.

Lindert, P. (2002). Voice and Growth: Was Churchill Right? (Working Papers with n. 02-6). Retrieved from University of California at Davis, Department of Economic website: http:/ / www.econ.ucdavis.edu/working-papers/02-6.pdf. 
Loayza, N, Oviedo, A., \& Serven, L. (2004). Regulation and Macroeconomic Performance. Unpublished manuscript, World Bank.

Marimon, R., \& Quadrini, V. (2006). Competition, Innovation and Growth with Limited Commitment. Unpublished manuscript, Universitat Pompeu Fabra and University of Southern California.

Marsh, R.M. (1988). Sociological Explanations of Economic Growth. Studies in Comparative International Development, 23(4). 41-76. doi:10.1007/BF02686984

North, D. (1990). Institutions, Institutional Change and Economic Performance. New York: Cambridge University Press.

Olson, M. (1982). The Rise and Decline of Nations. New Heaven: Yale University Press.

Olson, M. (1993). Dictatorship, Democracy and Development. The American Political Science Review, 87(3). 567-576. doi:10.2307/2938736

Parente, S.L. \& Prescott, E.C. (1994). Barriers to Technology Adoption and Development. Journal of Political Economy, 102(2). 298-321. doi:10.1086/261933

Przeworski, A., \& Limongi, F. (1993). Political Regimes and Economic Growth. The Journal of Economic Perspectives, 7(3). 51-69.

Rodrik, D. (1997). Democracy and Economic Performance. Unpublished manuscript, Harvard University.

Rodrik, D. (1999). Where Did All the Growth Go? External Shocks, Social Conflict, and Growth Collapses. Journal of Economic Growth, 4(4). 385-412. doi:10.1023/A:1009863208706

Rodrik, D. (2000). Participatory Politics, Social Cooperation, and Economic Stability. American Economic Review, 90(2). 140-144. doi:10.1257/aer.90.2.140

Roomdan, D. (2006). How to do xtabond2: An introduction to "system" and "difference" GMM in Stata. (Center for Global Development Working Paper 103). Retrieved from: http://repec.org/nasug2006/howtodoxtabond2.cgdev.pdf

Sah, P.K. (1991). Fallibility in Human Organizations and Political Systems. Journal of Economic Perspectives, 5(2). 67-88. Retrieved from: http://www.jstor.org/stable/1942686

Tavares, J., \& Wacziarg, R. (2001). How Democracy Affects Growth. European Economic Review, 45(8). 1341-79. doi:10.1016/S0014-2921(00)00093-3 
Weede, E. (1983). The Impact of Democracy on Economic Growth: Some Evidence from Cross-National Analysis. Kyklos, 36(1). 21-39. doi:10.1111/j.1467-6435.1983.tb02659.x 


\section{Appendix}

Table A1 - OLS Regression Results While Using GDP Per Capita Growth as a Dependent Variable

\begin{tabular}{|c|c|c|c|c|c|c|c|c|c|c|}
\hline Variable & Model 1 & Model 2 & Model 3 & Model 4 & Model 5 & Model 6 & Model 7 & Model 8 & Model 9 & Model 10 \\
\hline Per capita GDP growth (lagged) & $\begin{array}{l}0.083 \\
(0.066)\end{array}$ & $\begin{array}{l}0.081 \\
(0.066)\end{array}$ & $\begin{array}{l}0.081 \\
(0.067)\end{array}$ & $\begin{array}{l}0.081 \\
(0.067)\end{array}$ & $\begin{array}{l}0.081 \\
(0.067)\end{array}$ & $\begin{array}{l}0.081 \\
(0.067)\end{array}$ & $\begin{array}{l}0.080 \\
(0.067)\end{array}$ & $\begin{array}{l}0.081 \\
(0.067)\end{array}$ & $\begin{array}{l}0.080 \\
(0.066)\end{array}$ & $\begin{array}{l}0.080 \\
(0.067)\end{array}$ \\
\hline Democracy (Freedom House) & $\begin{array}{l}0.122 \\
(0.138)\end{array}$ & $\begin{array}{c}-0.681 \\
(0.709)\end{array}$ & --- & --- & --- & --- & --- & $-\cdots$ & ---- & --- \\
\hline Democracy (Freedom House) squared & --- & $\begin{array}{l}0.101 \\
(0.096)\end{array}$ & $-\cdots-$ & --- & $-\cdots-$ & ---- & ---- & --- & $-\ldots$ & --- \\
\hline Polity & --- & --- & $\begin{array}{l}0.010 \\
(0.028)\end{array}$ & $\begin{array}{l}0.011 \\
(0.029)\end{array}$ & --- & --- &.-- & $\begin{array}{l}0.010 \\
(0.029)\end{array}$ &.--- & $\begin{array}{l}0.032 \\
(0.031)\end{array}$ \\
\hline Polity squared & $\ldots-$ & $\cdots-$ & --- & $\begin{array}{l}-0.0007 \\
(0.006)\end{array}$ & --- & $\ldots$ & --- & --- & --- & --- \\
\hline Polity (transformed) & --- & --- & --- & $\ldots-$ & $\begin{array}{l}0.010 \\
(0.028)\end{array}$ & $\begin{array}{l}0.025 \\
(0.146)\end{array}$ & --- & --- & --- & --- \\
\hline Polity transformed (squared) & $\ldots-$ & $\ldots-$ & $\cdots-$ & $\ldots-$ & $\ldots-$ & $\begin{array}{l}-0.0007 \\
(0.006)\end{array}$ & --- & --- & --- & --- \\
\hline Regime durability & --- & --- & --- & --- & --- & --- & $\begin{array}{l}-0.00008 \\
(0.005)\end{array}$ & $\begin{array}{l}0.0002 \\
(0.006)\end{array}$ & --- & ---- \\
\hline Democracy (Cheibub) &.-- & --- & --- & --- & $-\cdots$ & $-\ldots-$ & --- & 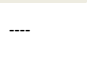 & $\begin{array}{l}0.029 \\
(0.362)\end{array}$ &.-- \\
\hline Interaction between Polity and durability &.-- & --- & --- & --- & --- & --- & --- & --- & ---- & $\begin{array}{l}-0.0009^{*} \\
(0.0005)\end{array}$ \\
\hline Number of observations & 669 & 669 & 667 & 667 & 667 & 667 & 669 & 667 & 669 & 667 \\
\hline Number of groups & 141 & 141 & 140 & 140 & 140 & 140 & 141 & 140 & 141 & 140 \\
\hline Rsquared & 0.215 & 0.220 & 0.213 & 0.213 & 0.213 & 0.213 & 0.213 & 0.213 & 0.213 & 0.216 \\
\hline
\end{tabular}

Note: in addition to the main independent variables, the following control variables are used: lagged value of the GDP per capita growth, log of the real GDP per capita (PPP), trade openness, inflation, life expectancy, population, gross secondary school enrollment and government expenditure. The sign, magnitude and the significance of the control variables correspond to the ones used in the empirical literature. ${ }^{* * *}$ denotes significance at 1 percent level of significance, ${ }^{* *}$ denotes signficance at 5 percent level of signficance, ${ }^{*}$ denotes signficance at 10 percent level of significance. Standard errors reported in parantheses.

Table A2 - OLS Regression Results While Using GDP Growth as a Dependent Variable

\begin{tabular}{|c|c|c|c|c|c|c|c|c|c|c|}
\hline Variable & Model 1 & Model 2 & Model 3 & Model 4 & Model 5 & Model 6 & Model 7 & Model 8 & Model 9 & Model 10 \\
\hline Per capita GDP growth (lagged) & $\begin{array}{l}0.042 \\
(0.066)\end{array}$ & $\begin{array}{l}.042 \\
(0.066)\end{array}$ & $\begin{array}{l}0.041 \\
(0.066)\end{array}$ & $\begin{array}{l}0.042 \\
(0.066)\end{array}$ & $\begin{array}{l}0.041 \\
(0.066)\end{array}$ & $\begin{array}{l}0.042 \\
(0.066)\end{array}$ & $\begin{array}{l}0.042 \\
(0.066)\end{array}$ & $\begin{array}{l}0.042 \\
(0.066)\end{array}$ & $\begin{array}{l}0.041 \\
(0.066)\end{array}$ & $\begin{array}{l}0.040 \\
(0.066)\end{array}$ \\
\hline Democracy (Freedom House) & $\begin{array}{l}0.094 \\
(0.123)\end{array}$ & $\begin{array}{l}-0.182 \\
(0.579)\end{array}$ & 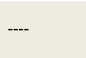 & -- & 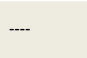 & -..- & $\ldots-$ & $-\cdots$ & 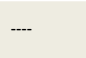 & -..- \\
\hline Democracy (Freedom House) squared & $\cdots$ & $\begin{array}{l}0.034 \\
(0.073)\end{array}$ & $\ldots-$ & $\ldots-$ & -..- & $\cdots$ & $\cdots$ & -..- & $-\cdots$ & $-\cdots-$ \\
\hline Polity & $-\cdots$ & $\ldots-$ & $\begin{array}{l}0.001 \\
(0.026)\end{array}$ & $\begin{array}{l}0.002 \\
(0.027)\end{array}$ & 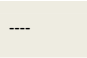 & $\ldots-$ & $-\cdots$ & $\begin{array}{l}0.001 \\
(0.027)\end{array}$ & --- & $\begin{array}{l}0.015 \\
(0.029)\end{array}$ \\
\hline Polity squared & $\ldots$ & $\ldots-$ & $\ldots-$ & $\begin{array}{l}-0.001 \\
(0.006)\end{array}$ & $\ldots-$ & $\ldots$ & $\cdots$ & -.-. & $\ldots-$ & $-\cdots-$ \\
\hline Polity (transformed) & -..- & $\ldots-$ & $\ldots-$ & $\ldots-$ & $\begin{array}{l}0.001 \\
(0.026)\end{array}$ & $\begin{array}{l}0.023 \\
(0.128)\end{array}$ & $\ldots$ & -..- & $\ldots-$ & $\ldots$ \\
\hline Polity transformed (squared) & $\cdots$ & $\cdots$ & $\cdots$ & $-\cdots-$ & $\cdots$ & $\begin{array}{l}-0.001 \\
(0.006)\end{array}$ & $\cdots$ & $\cdots$ & $\cdots$ & $\cdots$ \\
\hline Regime durability & $\ldots-$ & $\ldots--$ & $\ldots-$ & 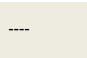 & --- & $-\cdots-$ & $\begin{array}{l}-0.001 \\
(0.006)\end{array}$ & $\begin{array}{l}-0.001 \\
(0.006)\end{array}$ & $-\cdots$ & -- \\
\hline Democracy (Cheibub) & $\ldots-$ & $\ldots--$ & $\ldots-$ & $\ldots--$ & -.-- & $\ldots--$ & $\ldots--$ & --- & $\begin{array}{l}-0.331 \\
(0.388)\end{array}$ & --- \\
\hline Interaction between Polity and durability & -.-- & $\ldots--$ & $\ldots--$ & 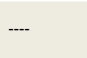 & 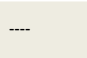 & --- & $-\cdots-$ & --- & --- & $\begin{array}{l}-0.0006 \\
(0.0005)\end{array}$ \\
\hline Number of observations & 661 & 661 & 659 & 659 & 659 & 659 & 661 & 659 & 660 & 659 \\
\hline Number of groups & 141 & 141 & 140 & 140 & 140 & 140 & 141 & 140 & 140 & 140 \\
\hline R squared & 0.179 & 0.180 & 0.175 & 0.176 & 0.175 & 0.176 & 0.174 & 0.176 & 0.179 & 0.176 \\
\hline
\end{tabular}

Note: in addition to the main independent variables, the following control variables are used: lagged value of the GDP per capita growth, log of the real GDP per capita (PPP), trade openness, inflation, life expectancy, population, gross secondary school enrollment and government expenditure. The sign, magnitude and the significance of the control variables correspond to the ones used in the empirical literature. ${ }^{* * *}$ denotes significance at 1 percent level of significance, ${ }^{* *}$ denotes signficance at 5 percent level of signficance, ${ }^{*}$ denotes signficance at 10 percent level of significance. Standard errors reported in parantheses. 
Commander, Nikoloski: Institutions and Economic Performance

Table B1 - FE Regression Results While Using GDP Per Capita Growth as a Dependent Variable

\begin{tabular}{|c|c|c|c|c|c|c|c|c|c|c|}
\hline Variable & Model 1 & Model 2 & Model 3 & Model 4 & Model 5 & Model 6 & Model 7 & Model 8 & Model 9 & Model 10 \\
\hline Per capita GDP growth (lagged) & $\begin{array}{c}-0.058 \\
(0.078)\end{array}$ & $\begin{array}{l}-0.059 \\
(0.079)\end{array}$ & $\begin{array}{l}-0.058 \\
(0.079)\end{array}$ & $\begin{array}{l}-0.058 \\
(0.078)\end{array}$ & $\begin{array}{l}-0.058 \\
(0.079)\end{array}$ & $\begin{array}{l}-0.058 \\
(0.079)\end{array}$ & $\begin{array}{l}-0.058 \\
(0.079)\end{array}$ & $\begin{array}{l}-0.058 \\
(0.079)\end{array}$ & $\begin{array}{l}-0.059 \\
(0.079)\end{array}$ & $\begin{array}{l}-0.066 \\
(0.079)\end{array}$ \\
\hline Democracy (Freedom House) & $\begin{array}{l}0.090 \\
(0.189)\end{array}$ & $\begin{array}{l}0.262 \\
(0.744)\end{array}$ & 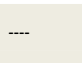 &.--- & 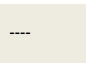 & $\cdots-$ & $\cdots-$ & $-\cdots$ & $\cdots--$ & -..- \\
\hline Democracy (Freedom House) squared & $\cdots-$ & $\begin{array}{l}-0.021 \\
(0.092)\end{array}$ & $\cdots--$ & $\cdots-$ & $\cdots-$ & $\cdots-$ & $\cdots-$ & $-\cdots$ & $-\cdots-$ & $-\cdots$ \\
\hline Polity & --- & 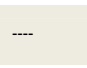 & $\begin{array}{l}0.018 \\
(0.041)\end{array}$ & $\begin{array}{l}0.015 \\
(0.041)\end{array}$ & & & & $\begin{array}{l}0.019 \\
(0.046)\end{array}$ & & $\begin{array}{l}0.031^{* *} \\
(0.015)\end{array}$ \\
\hline Polity squared & -..- & -..- & --- & $\begin{array}{l}0.004 \\
(0.007)\end{array}$ & --- & $\ldots$ & -..- & $-\cdots$ & --- & --- \\
\hline Polity (transformed) & $\cdots-$ & --- & --- & --- & $\begin{array}{l}0.018 \\
(0.041)\end{array}$ & $\begin{array}{l}-0.073 \\
(0.157)\end{array}$ & $-\ldots$ & $-\cdots$ & -..- & 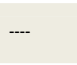 \\
\hline Polity transformed (squared) & $\cdots-$ & $-\cdots-$ & $\cdots--$ & $\cdots-$ & $-\cdots-$ & $\begin{array}{l}0.004 \\
(0.007)\end{array}$ & $\cdots-$ & $-\cdots-$ & -.-- & $\cdots-$ \\
\hline Regime durability & -.- & 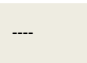 & --- & --- & --- & -- & $\begin{array}{l}-0.002 \\
(0.016)\end{array}$ & $\begin{array}{l}0.0006 \\
(0.018)\end{array}$ & --- & $-\cdots$ \\
\hline Democracy (Cheibub) & --- & --- & --- & --- & 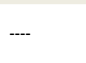 & $\ldots$ & $\ldots-$ & $-\cdots-$ & $\begin{array}{l}-0.229 \\
(0.522)\end{array}$ &.-- \\
\hline Interaction between Polity and durability & -.-. & $-\cdots$ & -.- & $\ldots-$ & -- & -- & -- & --- & --- & $\begin{array}{l}-0.002 \\
(0.002)\end{array}$ \\
\hline Number of observations & 669 & 669 & 667 & 667 & 667 & 667 & 669 & 667 & 669 & 667 \\
\hline Number of groups & 141 & 141 & 140 & 140 & 140 & 140 & 141 & 140 & 141 & 140 \\
\hline Rsquared & 0.120 & 0.120 & 0.116 & 0.114 & 0.116 & 0.114 & 0.118 & 0.116 & 0.118 & 0.131 \\
\hline
\end{tabular}

Note: in addition to the main independent variables, the following control variables are used: lagged value of the GDP per capita growth, log of the real GDP per capita (PPP), trade openness, inflation, life expectancy, population, gross secondary school enrollment and government expenditure. The sign, magnitude and the significance of the control variables correspond to the ones used in the empirical literature. ${ }^{* \star *}$ denotes significance at 1 percent level of significance, ${ }^{* *}$ denotes signficance at 5 percent level of signficance, ${ }^{*}$ denotes signficance at 10 percent level of significance. Standard errors reported in parantheses.

Table B2. FE Regression Results While Using GDP Growth as a Dependent Variable

\begin{tabular}{|c|c|c|c|c|c|c|c|c|c|c|}
\hline Variable & Model 1 & Model 2 & Model 3 & Model 4 & Model 5 & Model 6 & Model 7 & Model 8 & Model 9 & Model 10 \\
\hline GDP growth (lagged) & $\begin{array}{l}0.028 \\
(0.055)\end{array}$ & $\begin{array}{l}0.030 \\
(0.054)\end{array}$ & $\begin{array}{l}0.028 \\
(0.055)\end{array}$ & $\begin{array}{l}0.027 \\
(0.055)\end{array}$ & $\begin{array}{l}0.028 \\
(0.055)\end{array}$ & $\begin{array}{l}0.027 \\
(0.055)\end{array}$ & $\begin{array}{l}0.027 \\
(0.055)\end{array}$ & $\begin{array}{l}0.028 \\
(0.055)\end{array}$ & $\begin{array}{l}0.028 \\
(0.055)\end{array}$ & $\begin{array}{l}0.023 \\
(0.054)\end{array}$ \\
\hline Democracy (Freedom House) & $\begin{array}{l}-0.213 \\
(0.174)\end{array}$ & $\begin{array}{l}-0.549 \\
(0.754)\end{array}$ & -+- & --- & --- & --- & --- & --- & --- & --- \\
\hline Democracy (Freedom House) squared & --- & $\begin{array}{l}0.041 \\
(0.088)\end{array}$ & $---\cdot$ & --- & --- & --- & --- & ---- & --- & --- \\
\hline Polity & 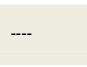 & --- & $\begin{array}{l}0.044 \\
(0.034)\end{array}$ & $\begin{array}{l}0.040 \\
(0.034)\end{array}$ & -..- & --- & --- & $\begin{array}{l}0.047 \\
(0.039)\end{array}$ & --- & $\begin{array}{l}0.066^{*} \\
(0.036)\end{array}$ \\
\hline Polity squared & --- & $---\cdot$ & $---\cdot$ & $\begin{array}{l}0.008 \\
(0.006)\end{array}$ & $-\cdots-$ & 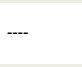 & $--\cdot$ & --- & --- & --- \\
\hline Polity (transformed) & $--\cdot-$ & --- & --- & --- & $\begin{array}{l}0.044 \\
(0.034)\end{array}$ & $\begin{array}{l}-0.122 \\
(0.131)\end{array}$ &.--- & --- & --- & -..- \\
\hline Polity transformed (squared) & $-\cdots$ & --- & --- & 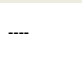 & --- & $\begin{array}{l}0.008 \\
(0.006)\end{array}$ & $\cdots-$ & $\ldots--$ & --- & $\cdots-$ \\
\hline Regime durability & --- & ---- & --- & --- & --- & --- & $\begin{array}{l}-0.004 \\
(0.014)\end{array}$ & $\begin{array}{l}0.002 \\
(0.017)\end{array}$ & --- & $\cdots$ \\
\hline Democracy (Cheibub) & $-\cdots$ & 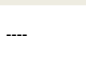 & --- & --- & --- & --- & $-\cdots-$ & --- & $\begin{array}{l}0.278 \\
(0.476)\end{array}$ & $\ldots-$ \\
\hline Interaction between Polity and durability & $-\cdots$ & $---\cdot$ & --- & --- & -- & --- & --- & --- & --- & $\begin{array}{l}-0.002 \\
(0.001)\end{array}$ \\
\hline Number of observations & 661 & 661 & 659 & 659 & 659 & 659 & 661 & 659 & 660 & 659 \\
\hline Number of groups & 141 & 141 & 140 & 140 & 140 & 140 & 141 & 140 & 140 & 150 \\
\hline Rsquared & 0.072 & 0.072 & 0.080 & 0.074 & 0.080 & 0.074 & 0.085 & 0.076 & 0.083 & 0.085 \\
\hline
\end{tabular}

Note: in addition to the main independent variables, the following control variables are used: lagged value of the GDP per capita growth, log of the real GDP per capita (PPP), trade openness, inflation, life expectancy, population, gross secondary school enrollment and government expenditure. The sign, magnitude and the significance of the control variables correspond to the ones used in the empirical literature. ${ }^{\star \star \star}$ denotes significance at 1 percent level of significance, ${ }^{\star \star}$ denotes signficance at 5 percent level of signficance, ${ }^{*}$ denotes signficance at 10 percent level of significance. Standard errors reported in parantheses. 